\title{
Pandemic induced lockdown as a boon to the Environment: trends in air pollution concentration across India
}

\author{
Alok Sagar Gautam ${ }^{1} \cdot$ Sanjeev Kumar ${ }^{1} \cdot$ Sneha Gautam ${ }^{2} \cdot$ Aryan Anand $^{3} \cdot$ Ranjit Kumar $^{4} \cdot$ Abhishek Joshi $^{1}$. \\ Kuldeep Bauddh ${ }^{5}$ Karan Singh ${ }^{1}$
}

Received: 10 October 2020 / Revised: 27 December 2020 / Accepted: 27 January 2021 / Published online: 1 February 2021

(C) Korean Meteorological Society and Springer Nature B.V. 2021

\begin{abstract}
The present paper designed to understand the variations in the atmospheric pollutants viz. $\mathrm{PM}_{10}, \mathrm{PM}_{2.5}, \mathrm{SO}_{2}, \mathrm{NO}_{2}$, and $\mathrm{CO}$ during the COVID-19 pandemic over eight most polluted Indian cities (Mumbai, Delhi, Bangalore, Hyderabad, Lucknow, Chandigarh, Kolkata, and Ahmedabad). A significant reduction in the $\mathrm{PM}_{2.5}(63 \%), \mathrm{PM}_{10}(56 \%), \mathrm{NO}_{2}(50 \%), \mathrm{SO}_{2}(9 \%)$, and CO (59\%) were observed over Major Dhyan Chand Stadium. At Chhatrapati Shivaji International Airport, a decline of $44 \%$ in $\mathrm{PM}_{2.5}$ and $50 \%$ in $\mathrm{PM}_{10}$ was seen just a week during the initial phase of the lockdown. Gaseous pollutants $\left(\mathrm{NO}_{2}, \mathrm{SO}_{2} \& \mathrm{CO}\right)$ dropped up-to 36, 16, and 41\%, respectively. The Air Quality Index (AQI) shows a dramatic change from $7 \%$ to $67 \%$ during observation at Chandigarh and Ballygunge during the inspection. Whereas, Ahmedabad, Worli, Income Tax Office, Talkatora, Lalbagh, and Ballygaunge have showed a significant change in AQI from $25.76 \%$ to $68.55 \%$. However, Zoo Park, CST, Central School, and Victoria show relatively low variation in AQI in the range of 3.0\% to $14.50 \%$ as compare to 2019 after lockdown. Hybrid Single-Particle Lagrangian Integrated Trajectory (HYSPLIT) analysis suggested that long range transportation of pollutants were also a part and parcel contributing to changes in AQI which were majorly coming from the regions of Iran, Afghanistan, Saudi Arabia, as well as a regional grant from Indian Gangatic plains and Delhi Non-capital region.
\end{abstract}

Keywords COVID- $19 \cdot$ Coronavirus $\cdot$ Air quality index $\cdot$ Back trajectories $\cdot$ India

Responsible Editor: Yunsoo Choi.

Sanjeev Kumar

sk8190179@gmail.com

Sneha Gautam

gautamsneha@gmail.com; snehagautam@karunya.edu

$\triangle$ Aryan Anand

aryananand2010@gmail.com

1 Department of Physics, Hemvati Nandan Bahuguna Garhwal University, Garhwal, Srinagar, Uttarakhand 246174, India

2 Karunya Institute of Technology and Sciences, Coimbatore, Tamil Nadu 641114, India

3 G B Pant National Institute of Himalayan Environment, Kosi Katarmal, Almora, India

4 Department of Chemistry, Faculty of Science, Dayalbagh Educational Institute (Deemed University), Dayalbagh, Agra 282005, India

5 Department of Environmental Sciences, Central University of Jharkhand, Ranchi 835205, India

\section{Introduction}

The 2019-n COVID-19 (novel corona) is a pneumonialike disease firstly reported to the World Health Organization (WHO) on 31 December 2019 which was originated in the Wuhan, China. It subsequently spread to other countries like Thailand, Italy, and USA etc. On 13 January 2020 , WHO initiated a national capacity review tools for the current status of laboratories and equipment capabilities to screen the virus (Driggin et al. 2020). On 30 January 2020, the first infection of a novel coronavirus in India was reported in Kerala, with a patient having travel history to China. The second case was reported in the next four days, thus Kerala (State of India) declared the state emergency on 4 February 2020. India was experiencing the condition of the epidemic, which had already turned out as a pandemic across the globe, so a complete lockdown was ordered in India on 22nd march 2020 by Prime Minister Modi (Gautam and Hens 2020a). Approximately $10,187,772$ positive cases and 147,665 reported deaths due to the pandemic on 27 
December 2020 in the India (The Hindu 2020). The developed countries enforced the lockdown to break the chain of the virus spread, which led to a domino effect in restoration of the degraded environment (improvements in the air, soil and water pollution levels) with a greater extent attributed due to less fuel burning and the least anthropogenic activity all around the world (Bao and Zhang 2020). The extreme event (COVID -19 virus spread) has potentially resulted in a decrease of particlebased pollution, including aerosols and other gaseous pollutants $\left(\mathrm{SO}_{2}, \mathrm{NO}_{2}, \mathrm{CO}\right.$ etc.) across the world (https:// www.theguardian.com/world $/ 2020 / \mathrm{mar} / 20 /$ coronavirusthe-week-the-world-shut-down) This unintentional pandemic has allowed the researchers to review the various aspects of the lockdown. The harmful atmospheric pollutants (APs) mainly emitted from industries, transportation, etc. were reduced to a significant level and resulting in further improvements in the environment in India (Sharma et al. 2020; Srivastava et al. 2020; Gautam et al. 2020; Gautam and Hens 2020b).

Several attempts have taken by the research community to understand the effects of a pandemic on air quality around the world (He et al. 2020; Berman and Ebisu 2020; Azuma et al. 2020). The presented manuscript is based on the dynamics of air quality parameters $\left(\mathrm{PM}_{10}, \mathrm{PM}_{2.5}, \mathrm{NO}_{2}, \mathrm{SO}_{2} \& \mathrm{CO}\right)$ across 17 stations in climatic zones in India. For this purpose, pollution data have obtained from central pollution control boards (CPCB) coupled with Hybrid Single Particle Lagrangian Integrated Trajectory (HYSPLIT) model to understating the trans-boundary movement of air mass (Draxler and Hess 1998).

As per the IQAir (2019) report, India contributed to six cities with maximum particulate pollution out often around the world. The air pollution parameters $\left(\mathrm{PM}_{2.5}, \mathrm{PM}_{10}, \mathrm{SO}_{2}\right.$, $\mathrm{NO}_{2}$, and $\mathrm{CO}$ ) have been drastically declined during the lockdown duration which have implemented as a precautious tool to control the location-specific pollutants that directly affect the human health (Cole et al. 2005; Sharma et al. 2020; Gautam and Trivedi 2020; Gautam and Hens 2020c). In the current situation the air pollution is undoubtedly one of the major issues of both developed and developing countries which can jeopardies the heath condition of the human as well as contain a direct impact on animals and floral species (Dixit and Tiwari 2008; Ghorani-Azam et al. 2016; Mannucci and Franchini 2017). So, it is very interesting to under impact of sudden change in pollution level due COIVD-19 outbreak.

The main purpose of this study is to quantify/ investigate the impact of the lockdown on the environment and look into the future aspects for the reduction of pollution level. Furthermore, the study quantifies the dynamics of APs, across the selected cities of the country when the humans are adhering to limited usage of resources like vehicles, kilns and factories, etc.

\section{Methodology and techniques}

\subsection{Selection of the study areas}

The study has carried out for the most polluted million-plus cities of India, where a total of 17-point locations across eight cities (Table. $1 \&$ Fig. 1). The mentioned sites were selected based on vehicle flux, population density and industrial operations factors that may directly or indirectly affects air quality. Also, the cities cover different agro-climatic and topographical zones viz. Coastal areas and plains.

\subsection{Dataset and variables}

The dataset of APs, i.e., $\mathrm{PM}_{2.5}, \mathrm{PM}_{10}, \mathrm{SO}_{2}$, $\mathrm{NO} 2$, and $\mathrm{CO}$, were extracted from the Central Pollution Control Board (CPCB). The National Air Quality Index (NAQI) were used to assess the actual impact of the lockdown in the years $2019 \& 2020$ with the same temporal duration (15 March to 10 May 2019 \& 2020) and plotted by using the Originlab (student version) software (Serial Number: GL3S4-6089-7,609,063). For those stations where, data was unavailable due to non-working instruments or other technical issues, data were extracted from the nearest monitoring stations. Such stations include Chatrapati Shivaji Terminal, Powai, and Worli in Mumbai, where the nearest available station was Bandra with a flying distance of $15 \mathrm{~km}, 9 \mathrm{~km}$, and $8 \mathrm{~km}$, respectively. Another station included Rabindra Sarovar and Ballygunge in Kolkata, which was replaced by Rabindra Bharti University with an aerial distance of $15 \mathrm{~km}$ and $13 \mathrm{~km}$, respectively. Chandigarh didn't have a running monitoring station till the last date of data acquisition. The study was focused on the impact of lockdown and how their concentrations differ when anthropogenic pressure on the environment was less due to a lower number of vehicles, factories shut down, and restricted human movement.

Air quality index (AQI) is a measurement of the air quality concerning different indicators. A mathematical relationship between the mass concentrations of APs and their health impacts as suggest by Sharma et al. (2003). The sub-index (Ip) for a particular pollutant $(\mathrm{Cp})$, is derived from the 'linear segmented principle' (Akolkar 2016).

$\mathrm{Ip}=\left[\left\{\left(\mathrm{I}_{\mathrm{HI}}-\mathrm{I}_{\mathrm{LO}}\right) /\left(\mathrm{B}_{\mathrm{HI}}-\mathrm{B}_{\mathrm{LO}}\right)\right\} *\left(\mathrm{Cp}-\mathrm{B}_{\mathrm{LO}}\right)\right]+\mathrm{I}_{\mathrm{LO}}$

$\mathrm{B}_{\mathrm{HI}}=$ Greater or equal breakpoint concentration of given concentration of APs.

$\mathrm{B}_{\mathrm{LO}}=$ Smaller or equal breakpoint concentration of given concentration of APs. 
Table 1 Location of monitoring sites

\begin{tabular}{|c|c|c|c|c|c|}
\hline State & District & City & Latitude & Longitude & Distance from Delhi $(\mathbf{k m})$ \\
\hline \multirow[t]{3}{*}{ Delhi } & \multirow[t]{3}{*}{ Delhi } & MDC National Stadium & 28.61307 & 77.23751 & 0 \\
\hline & & ITO & 28.63236 & 77.25059 & 2.2 \\
\hline & & Wazipur & 28.69987 & 77.16028 & 18.9 \\
\hline \multirow[t]{3}{*}{ Uttar Pradesh } & \multirow[t]{3}{*}{ Lucknow } & Talkatora District Industries Center & 26.8345 & 80.89599 & 543.6 \\
\hline & & Lalbagh & 26.84679 & 80.94132 & 552.8 \\
\hline & & Central School & 26.88674 & 80.94397 & 563.1 \\
\hline \multirow[t]{3}{*}{ West Bengal } & \multirow[t]{3}{*}{ Kolkata } & Victoria & 22.54508 & 88.34252 & 1537.9 \\
\hline & & Rabindra Sarovar & 22.51223 & 88.36368 & 1544.1 \\
\hline & & Ballygunge & 22.52871 & 88.36499 & 1542.3 \\
\hline \multirow[t]{2}{*}{ Telangana } & \multirow[t]{2}{*}{ Hyderabad } & Zoo Park & 17.35082 & 78.45132 & 1577.8 \\
\hline & & Sanathnagar & 17.45669 & 78.44386 & 1566.8 \\
\hline Karnataka & Bengaluru & Hebbal & 13.036 & 77.59877 & 2156.3 \\
\hline \multirow[t]{3}{*}{ Maharashtra } & \multirow[t]{3}{*}{ Mumbai } & CSI Airport & 19.09013 & 72.86519 & 1409.3 \\
\hline & & Powai & 19.11864 & 72.90651 & 1410.5 \\
\hline & & Worli & 18.99898 & 72.81667 & 1424.6 \\
\hline Chandigarh & Chandigarh & Sector 25 & 30.75224 & 76.75902 & 245.9 \\
\hline Gujrat & Ahmedabad & Maninagar & 22.9955 & 72.60421 & 951.8 \\
\hline
\end{tabular}

$\mathrm{I}_{\text {H.I. }}=\mathrm{AQI}$ value corresponding to greater or equal breakpoint concentration. $\mathrm{I}_{\text {..O. }}=\mathrm{AQI}$ value corresponding to smaller or equal breakpoint concentration.

or, $\mathrm{AQI}=$ Maximum (Ip) (where; $p=1,2, \mathrm{n}$; denotes $\mathrm{n}$ APs).

The AQI is divided into six different categories for individual pollutants such as Good (0-50), Satisfactory (51-100), Moderate (101-200), Poor (201-300), Very Poor (301-400) $\&$ Sever (401-500) as mentioned in the Table 2 (Akolkar 2016).

Now, To identify the pollutant source, the Air mass back trajectories were derived from National Oceanic and Atmospheric Administration (NOAA) and HYSPLIT model (Draxler and Hess 1998). Further data were plotted by using Meteoinfo software. The profile of meteorological dataset at each horizontal grid points is linearly interpolated to a terrain-following $(\mathrm{F})$ coordinate system,

$\sigma=1-\mathrm{z} / \mathrm{Z}_{\mathrm{top}}$

Where $Z_{\text {top }}$ is the top of HYSPLIT's coordinate system.

The velocity $(\mathrm{W})$ to maintain a parcel on the selected $(0)$ surface is computed from,

$\mathrm{W} \eta=(-\partial / \partial \mathrm{t}-\mathrm{u} \partial \mathrm{\eta} / \partial \mathrm{x}-\mathrm{v} \partial \eta / \partial \mathrm{y}) /(\partial \eta / \partial \mathrm{z})$

For advection components in the model, the velocity vectors are linearly interpolated in space and time, and the first guess position is obtained from,
$\mathrm{P}^{\prime}(\mathrm{t}+\partial \mathrm{t})=\mathrm{P}(\mathrm{t})+\mathrm{V}(\mathrm{P}, \mathrm{t}) \partial \mathrm{t}$

And mathematically, the final position is,

$\mathrm{P}(\mathrm{t}+\partial \mathrm{t})=\mathrm{P}(\mathrm{t})+0.5\left[\mathrm{~V}(\mathrm{P}, \mathrm{t})+\mathrm{V}\left(\mathrm{P}^{\prime}, \mathrm{t}+\partial \mathrm{t}\right)\right] \partial \mathrm{t}$

\section{Results and Discussion}

Air quality Index showed a significant improvement within 24-h of the implementation of lockdown due to a low use of fuel-powered vehicles and factories shut down. All the monitoring stations have shown improved quality of air within the first week of lockdown. The significant contribution of the lockdown regarding air quality at different studied locations is as follows.

\subsection{Mumbai and Maharashtra}

Mumbai is one of the populous cities of India with highend infrastructure that had showed prominent impacts in improving the air quality. The $\mathrm{PM}_{2.5}$ shifted from $183 \mu \mathrm{g} /$ $\mathrm{m}^{3}$ to $63 \mu \mathrm{g} / \mathrm{m}^{3}$, and $\mathrm{PM}_{10}$ dropped from a weekly average of $145.71 \pm 57.82 \mu \mathrm{g} / \mathrm{m}^{3}$ to $73.14 \pm 12.2 \mu \mathrm{g} / \mathrm{m}^{3}$ over Chhatrapati Shivaji International (CST) airport after lockdown (Fig. 2a). The $\mathrm{NO}_{2}, \mathrm{SO}_{2}$, and $\mathrm{CO}$, also showed a sharp decline of 36, 16, and $41 \%$, respectively (Fig. 2a). In Powai, a consistent decline in all major pollutants observed after the lockdown (Fig. 2a). The weekly average 


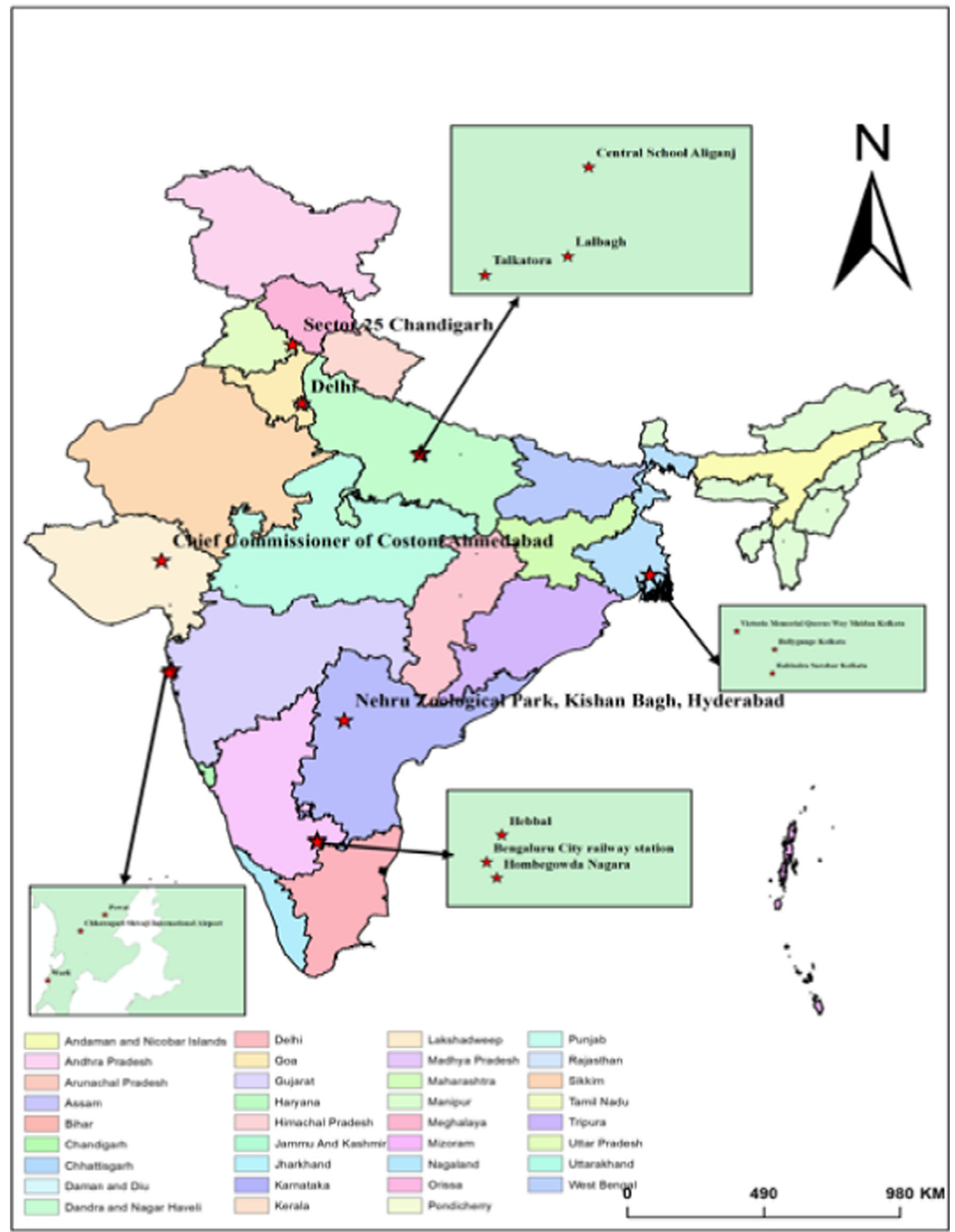

Fig. 1 Location of observational sites across India

concentrations of pollutants before lockdown were 67.14 $\pm 25.69 \mu \mathrm{g} / \mathrm{m}^{3}\left(\mathrm{PM}_{2.5}\right), 95.14 \pm 29.95 \mu \mathrm{g} / \mathrm{m}^{3}\left(\mathrm{PM}_{10}\right)$, $18.57 \pm 7.50 \mu \mathrm{g} / \mathrm{m}^{3}\left(\mathrm{NO}_{2}\right), 4.71 \pm 1.79 \mu \mathrm{g} / \mathrm{m}^{3}\left(\mathrm{SO}_{2}\right)$ and $48.57 \pm 9.79 \mu \mathrm{g} / \mathrm{m}^{3}(\mathrm{CO})$ and in the first week after lockdown, the levels declined to $52.14 \pm 14.29 \mu \mathrm{g} / \mathrm{m}^{3}$ for $\mathrm{PM}_{2.5}(-26 \%), 69.28 \pm 15.90 \mu \mathrm{g} / \mathrm{m}^{3}$ for $\mathrm{PM}_{10}(-27 \%)$,
$5.85 \pm 2.26 \mu \mathrm{g} / \mathrm{m}^{3}$ for $\mathrm{NO}_{2}(-13 \%)$, and $69.28 \pm$ $15.90 \mu \mathrm{g} / \mathrm{m}^{3}$ for CO $(-20 \%)$. Moreover, the lowest values of pollutant concentration during the entire lockdown observational data were $15 \mu \mathrm{g} / \mathrm{m}^{3}\left(\mathrm{PM}_{2.5}\right), 21 \mu \mathrm{g} / \mathrm{m}^{3}$ $\left(\mathrm{PM}_{10}\right), 1 \mu \mathrm{g} / \mathrm{m}^{3}\left(\mathrm{NO}_{2}\right), 3 \mu \mathrm{g} / \mathrm{m}^{3}\left(\mathrm{SO}_{2}\right)$ and $2 \mu \mathrm{g} / \mathrm{m}^{3}$ (CO). The concentration of $\mathrm{SO}_{2}$ increased after 5 th week 
Table 2 National AQI and concentration ranges of the pollutants. (Akolkar 2016).

\begin{tabular}{llllllll}
\hline AQI CLASS & $\mathbf{P M}_{10}$ & $\mathbf{P M}_{2.5}$ & $\mathbf{N O}_{2}$ & NH $_{3}$ & $\mathbf{S O}_{2}$ & $\mathbf{C O}$ & $\mathbf{O}_{3}$ \\
(RANGE) & $24-\mathrm{hrs}$ & $24-\mathrm{hrs}$ & $24-\mathrm{hrs}$ & $24-\mathrm{hrs}$ & $24-\mathrm{hrs}$ & 8 -hrs & 8 -hrs \\
& $\left(\mu \mathrm{g} / \mathrm{m}^{3}\right)$ & $\left(\mu \mathrm{g} / \mathrm{m}^{3}\right)$ & $\left(\mu \mathrm{g} / \mathrm{m}^{3}\right)$ & $\left(\mu \mathrm{g} / \mathrm{m}^{3}\right)$ & $\left(\mu \mathrm{g} / \mathrm{m}^{3}\right)$ & $\left(\mathrm{mg} / \mathrm{m}^{3}\right)$ & $\left(\mu \mathrm{g} / \mathrm{m}^{3}\right)$
\end{tabular}

\section{CONCENTRATION RANGE}

\begin{tabular}{|c|c|c|c|c|c|c|c|}
\hline $\begin{array}{l}\text { GOOD } \\
(0-50)\end{array}$ & $0-50$ & $0-30$ & $0-40$ & $0-200$ & $0-40$ & $0-1$ & $0-50$ \\
\hline $\begin{array}{l}\text { SATISFACTORY } \\
(51-100)\end{array}$ & $51-100$ & $31-60$ & $41-80$ & $201-400$ & $41-80$ & $1.1-2$ & $51-100$ \\
\hline $\begin{array}{l}\text { MODERATE } \\
(101-200)\end{array}$ & $101-250$ & $61-90$ & $81-180$ & $401-800$ & $81-380$ & $2.1-10$ & $101-168$ \\
\hline $\begin{array}{l}\text { POOR } \\
(201-300)\end{array}$ & $251-350$ & $91-120$ & $181-280$ & $801-1200$ & $381-800$ & $10-17$ & $169-208$ \\
\hline $\begin{array}{l}\text { VERY POOR } \\
(301-400)\end{array}$ & $351-430$ & $121-250$ & $281-400$ & $\begin{array}{l}1200- \\
1800\end{array}$ & $801-1600$ & $17-34$ & 209-748 \\
\hline $\begin{array}{l}\text { SEVERE } \\
(401-500)\end{array}$ & $>430$ & $>250$ & $>400$ & $>1800$ & $>1600$ & $>34$ & $>748$ \\
\hline
\end{tabular}

that may be due to relaxation in lockdown and long-range transportation of pollutants (Srivastava et al. 2020).

The third location in Mumbai, i.e., Worli, also showed a convincing response towards the reduction in air contaminants after the lockdown period. The highest and lowest level of $\mathrm{PM}_{2.5}$ during the week before lockdown implementation were 183 and $27 \mu \mathrm{g} / \mathrm{m}^{3}$ respectively, 161 and $50 \mu \mathrm{g} / \mathrm{m}^{3}$ for $\mathrm{PM}_{10}$ respectively and 57 and $18 \mu \mathrm{g} / \mathrm{m}^{3}$ for $\mathrm{NO}_{2}, 18$ and $6 \mu \mathrm{g} / \mathrm{m}^{3}$ $\mathrm{SO}_{2}$ and 48 and $10 \mu \mathrm{g} / \mathrm{m}^{3} \mathrm{CO}$. Within a week, gradual decline in weekly averages of pollutant was observed with values of $48.28 \pm 12.75 \mu \mathrm{g} / \mathrm{m}^{3}$ for $\mathrm{PM}_{2.5}(-63 \%), 64.71 \pm 14.49 \mu \mathrm{g} / \mathrm{m}^{3}$ for $\mathrm{PM}_{10}(-39 \%), 9 \pm 2.08 \mu \mathrm{g} / \mathrm{m}^{3}$ for $\mathrm{NO}_{2}(-38 \%), 5.42 \pm$ $0.53 \mu \mathrm{g} / \mathrm{m}^{3}$ for $\mathrm{SO}_{2}(-46 \%)$, and $12 \pm 3.26 \mu \mathrm{g} / \mathrm{m}^{3}$ for $\mathrm{CO}$ $(-57 \%)$. Chauhan and Singh (2020) observed a decline of $\mathrm{PM}_{2.5}$ concentration across different main cities across world and observed $14 \%$ decrease in the $\mathrm{PM}_{2.5}$ as compared to March 2019 (last year) over Mumbai. Ramasamy et al. (2020) also, showed a reduction in the AQI of Mumbai by $62 \%$ after the imposition of lockdown.

\subsection{Delhi}

The capital city of India showed a remarkable drop in pollution parameters. The Major Dhyan Chand (MDC) stadium showed a declining trend in pollution since after lockdown (Fig. 2b). The average concentration of $\mathrm{PM}_{2.5}\left(119.42 \pm 33.92 \mu \mathrm{g} / \mathrm{m}^{3)}, \mathrm{PM}_{10}\right.$ $\left(124 \pm 17.67 \mu \mathrm{g} / \mathrm{m}^{3}\right) \mathrm{NO}_{2},\left(60.71 \pm 6.80 \mu \mathrm{g} / \mathrm{m}^{3}\right) \mathrm{SO}_{2}(27.28 \pm$ $\left.6.47 \mu \mathrm{g} / \mathrm{m}^{3}\right)$ and $\mathrm{CO}\left(23 \pm 6.08 \mu \mathrm{g} / \mathrm{m}^{3}\right)$ was observed a week before lockdown. A decline of $63 \%$ in $\mathrm{PM}_{2.5}, 56 \%$ in $\mathrm{PM}_{10}, 50 \%$ in $\mathrm{NO}_{2}, 9 \%$ in $\mathrm{SO}_{2}$, and $59 \%$ in $\mathrm{CO}$ have reported after lockdown. The pollution parameter in the 7th week of lockdown reduced to $64.88 \pm 20.66 \mu \mathrm{g} / \mathrm{m}^{3}\left(\mathrm{PM}_{2.5}\right), 81.50 \pm 21.44 \mu \mathrm{g} / \mathrm{m}^{3}$
$\left(\mathrm{PM}_{10}\right), 19.13 \pm 3.64 \mu \mathrm{g} / \mathrm{m}^{3}\left(\mathrm{NO}_{2}\right), 23.13 \pm 1.55 \mu \mathrm{g} / \mathrm{m}^{3}\left(\mathrm{SO}_{2}\right)$ and $19.25 \pm 3.19 \mu \mathrm{g} / \mathrm{m}^{3}(\mathrm{CO})$.

At Income Tax Office (ITO), the weekly average concentration observed $180.83 \pm 52.94 \mu \mathrm{g} / \mathrm{m}^{3}$ of $\mathrm{PM}_{2.5}, 121.16 \pm$ $21.19 \mu \mathrm{g} / \mathrm{m}^{3}$ of $\mathrm{PM}_{10}, 66.16 \pm 4.53 \mu \mathrm{g} / \mathrm{m}^{3}$ of $\mathrm{NO}_{2}, 21.50 \pm$ $8.60 \mu \mathrm{g} / \mathrm{m}^{3}$ of $\mathrm{SO}_{2}$ and $29.83 \pm 29.08 \mu \mathrm{g} / \mathrm{m}^{3}$ of CO. Decrease of $49 \%$ in $\mathrm{PM}_{2.5}, 46 \%$ in $\mathrm{PM}_{10}, 33 \%$ in $\mathrm{NO}_{2}, 56 \%$ in $\mathrm{SO}_{2}$ also reported after lockdown. However, there was no substantial change in $\mathrm{CO}$ concentration as compared to before-lockdown (Fig. 2b). In the Wazirpur, the decline of pollutants is also not convincing. However, the pollutants declined gradually during the timeline. They were effortlessly low by the third week of the lockdown implementation, further gained peaks in the fourth week, which may be due to the restarting of transportation (earlier mansion). The weekly average of pollutant concentration before the lockdown was $18,042.09 \mu \mathrm{g} / \mathrm{m}^{3}$ of $\mathrm{PM}_{2.5}, 184.14 \pm 39.55 \mu \mathrm{g} / \mathrm{m}^{3}$ of $\mathrm{PM}_{10}, 60.14 \pm 3.63 \mu \mathrm{g} / \mathrm{m}^{3}$ of $\mathrm{NO}_{2}$ and $92 \pm 11.10 \mu \mathrm{g} / \mathrm{m}^{3}$ of $\mathrm{CO}$. The values of $\mathrm{SO}_{2}$ were deficient in calculating the pollutants in the week. The overall highest and lowest concentration of pollutants during the lockdown was 223 and $36 \mu \mathrm{g} / \mathrm{m}^{3}$ of $\mathrm{PM}_{2.5}, 183$ and $45 \mu \mathrm{g} / \mathrm{m}^{3}$ of $\mathrm{PM}_{10}, 58$ and $25 \mu \mathrm{g} / \mathrm{m}^{3}$ of $\mathrm{NO}_{2}, 35$ and $13 \mu \mathrm{g} / \mathrm{m}^{3}$ of $\mathrm{SO}_{2}$ and 106 and $53 \mu \mathrm{g} / \mathrm{m}^{3}$ of CO (Fig. 2b). A study led by Chauhan and Singh (2020) across 9 cities across the world described a declining trend in $\mathrm{PM}_{2.5}$ concentration over Indian megacities, i.e., Delhi and Mumbai contributing 35 and 14\% respectively.

\subsection{Bangalore, Karnataka, India}

Most of the locations in Bangalore have a better air quality compared to other million-plus cities. Within the first week of lockdown implementation, there was no noticeable difference 
Fig. 2 Daily variation of atmospheric pollutant over (a) Mumbai $\left(\mathrm{a} 1 ; \mathrm{PM}_{10}, \& \mathrm{PM}_{2.5}\right.$, and a2; $\mathrm{NO}_{2}, \mathrm{SO}_{2} \& \mathrm{CO}$ ) and (b) Delhi (b1; $\mathrm{PM}_{10}, \& \mathrm{PM}_{2.5}$, and b2; $\mathrm{NO}_{2}, \mathrm{SO}_{2}$ \& $\left.\mathrm{CO}\right)$ during 15 March 2020 to 10 April 2020. A dark black line is used to distinguish the before (before 24 March 2020) and after (after 24 March 2020) lockdown period

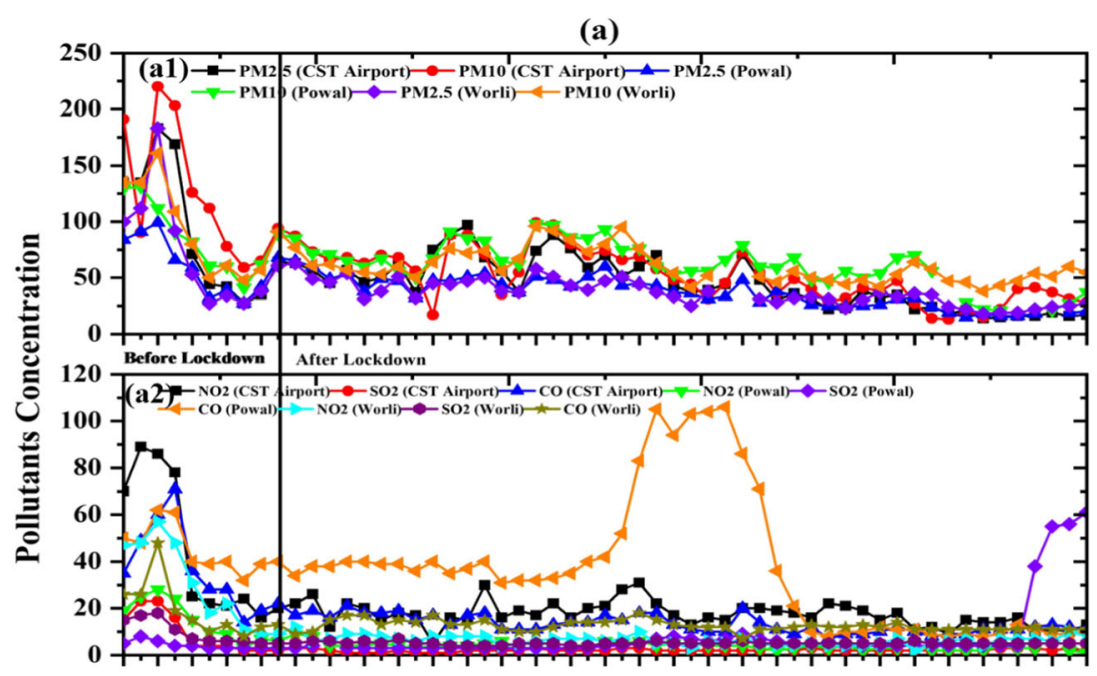

(b)

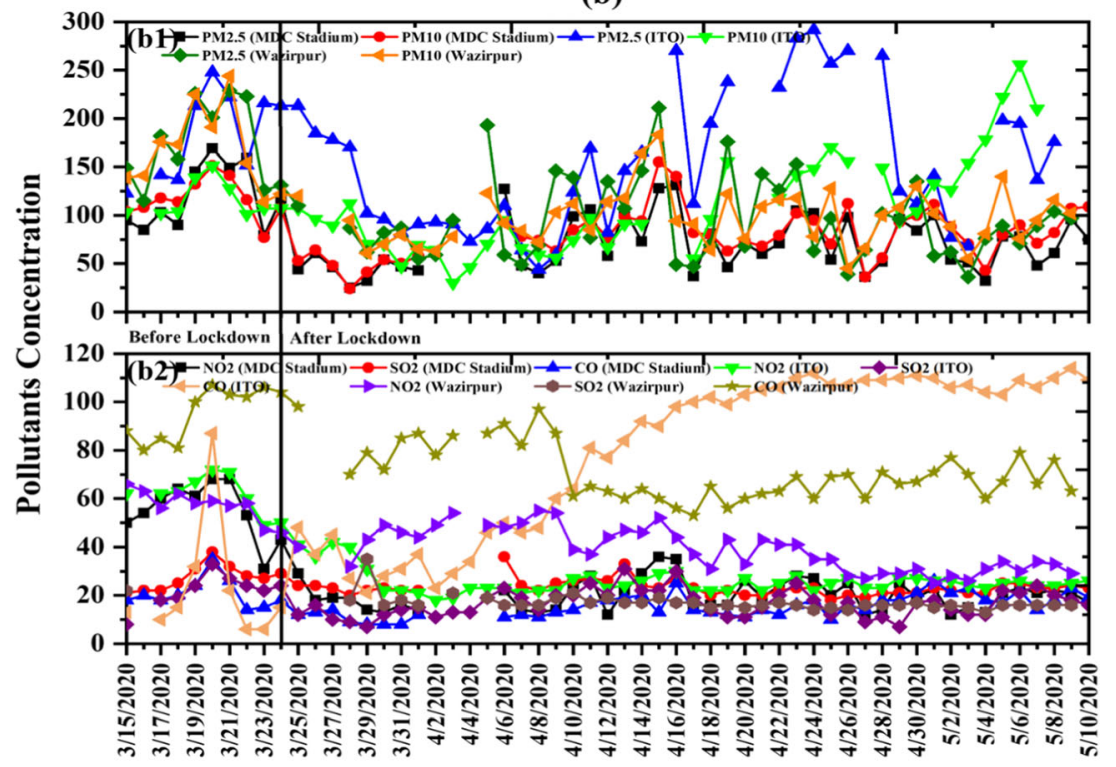

Date in pollutant concentrations until the 5th week. The average weekly levels were $44.57 \pm 13.80 \mu \mathrm{g} / \mathrm{m}^{3}\left(\mathrm{PM}_{2.5}\right), 71.85 \pm$ $9.28 \mu \mathrm{g} / \mathrm{m}^{3}\left(\mathrm{PM}_{10}\right), 9.85 \pm 1.34 \mu \mathrm{g} / \mathrm{m}^{3}\left(\mathrm{NO}_{2}\right), 11.28 \pm$ $2.92 \mu \mathrm{g} / \mathrm{m}^{3}\left(\mathrm{SO}_{2}\right), 36.42 \pm 10.48 \mu \mathrm{g} / \mathrm{m}^{3}$ (CO) before lockdown, which decreases $37 \%$ in $\mathrm{PM}_{2.5}, 41 \%$ in $\mathrm{PM}_{10}, 65 \%$ in $\mathrm{NO}_{2}$, whereas $\mathrm{SO}_{2}$ and $\mathrm{CO}$ were reduced by 23 and $21 \%$ respectively by 5 th week. The highest and lowest concentrations during the lockdown were 96 and $17 \mu \mathrm{g} / \mathrm{m}^{3}$ for $\mathrm{PM}_{2.5}$, 97 and $25 \mu \mathrm{g} / \mathrm{m}^{3}$ for $\mathrm{PM}_{10}, 9$ and $2 \mu \mathrm{g} / \mathrm{m}^{3}$ for $\mathrm{NO}_{2}, 17$ and $7 \mu \mathrm{g} / \mathrm{m}^{3}$ for $\mathrm{SO}_{2}$ and $\mathrm{CO}$ concentrations stand at $50 \mu \mathrm{g} / \mathrm{m}^{3}$ and $6 \mu \mathrm{g} / \mathrm{m}^{3}$ (Fig. 3a).

\subsection{Hyderabad, Telangana, India}

Hyderabad also, performed well during the lockdown in terms of pollutant reduction. The available data gave a clear picture of the decline in pollutants within a couple of weeks. A major reduction in $\mathrm{NO}_{2}$ observed during the study, with a decline of $46 \%$ within two weeks of lockdown. However, $\mathrm{NO}_{2}$ concentration also increased to similar levels before lockdown. Other pollutants also declined by the eight weeks of lockdown implementation. The weekly average level of pollutants before lockdown were $81.85 \pm 15.36 \mu \mathrm{g} / \mathrm{m}^{3}\left(\mathrm{PM}_{2.5}\right), 91.85 \pm$ $8.61 \mu \mathrm{g} / \mathrm{m}^{3}\left(\mathrm{PM}_{10}\right), 51.28 \pm 3.35 \mu \mathrm{g} / \mathrm{m}^{3}\left(\mathrm{NO}_{2}\right), 2.71 \pm$ $0.76 \mu \mathrm{g} / \mathrm{m}^{3}\left(\mathrm{SO}_{2}\right)$ and $58.28 \pm 6.23 \mu \mathrm{g} / \mathrm{m}^{3}$ (CO). The weekly pollutants in the second last week (sixth week) of the study were $65.40 \pm 3.91 \mu \mathrm{g} / \mathrm{m}^{3}\left(\mathrm{PM}_{2.5}\right), 59.57 \pm 4.07 \mu \mathrm{g} / \mathrm{m}^{3}\left(\mathrm{NO}_{2}\right)$, $4.28 \pm 0.75 \mu \mathrm{g} / \mathrm{m}^{3}\left(\mathrm{SO}_{2}\right)$ and $31.28 \pm 19.49 \mu \mathrm{g} / \mathrm{m}^{3}(\mathrm{CO})$. The gaseous pollutants have observed to be increasing after a few weeks of lockdown, which was due to the relaxations given to the public (Srivastava et al. 2020). The trends in APs have inscribed in Fig. 3b. Lokhandwala and Gautam et al. (2020) 
Fig. 3 Daily variation of atmospheric pollutant over (a) Bangalore and (b) Hyderabad during 15 March 2020 to 10 April 2020. A dark black line is used to distinguish the before (before 24 March 2020) and after (after 24 March 2020) lockdown period

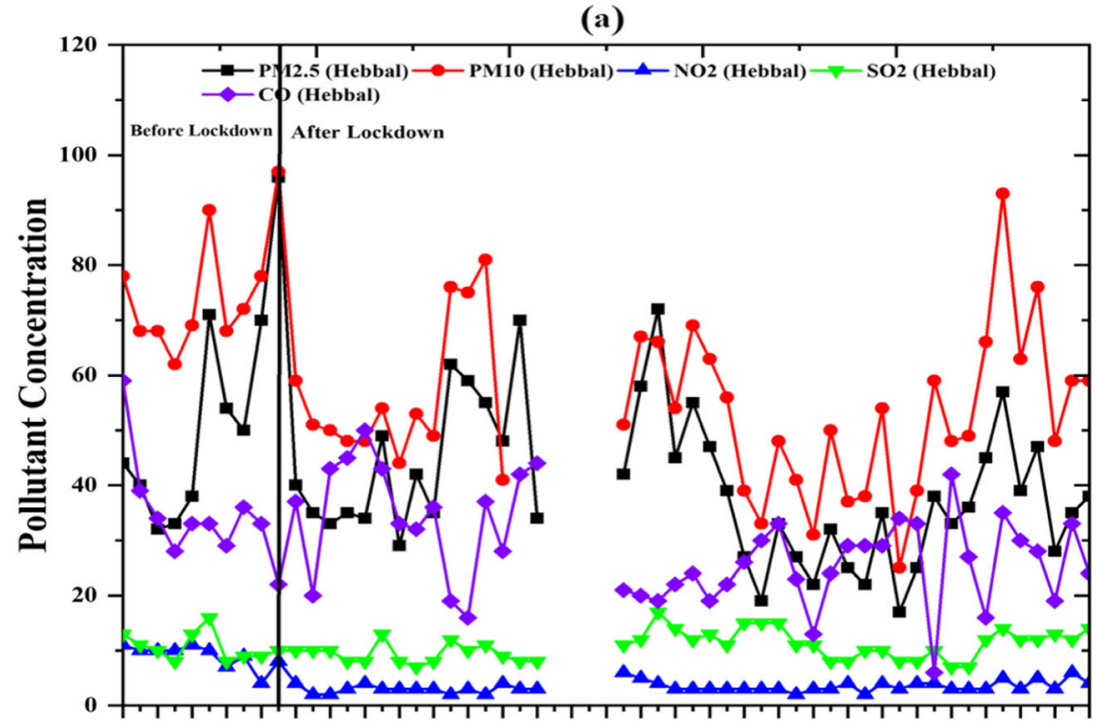

(b)

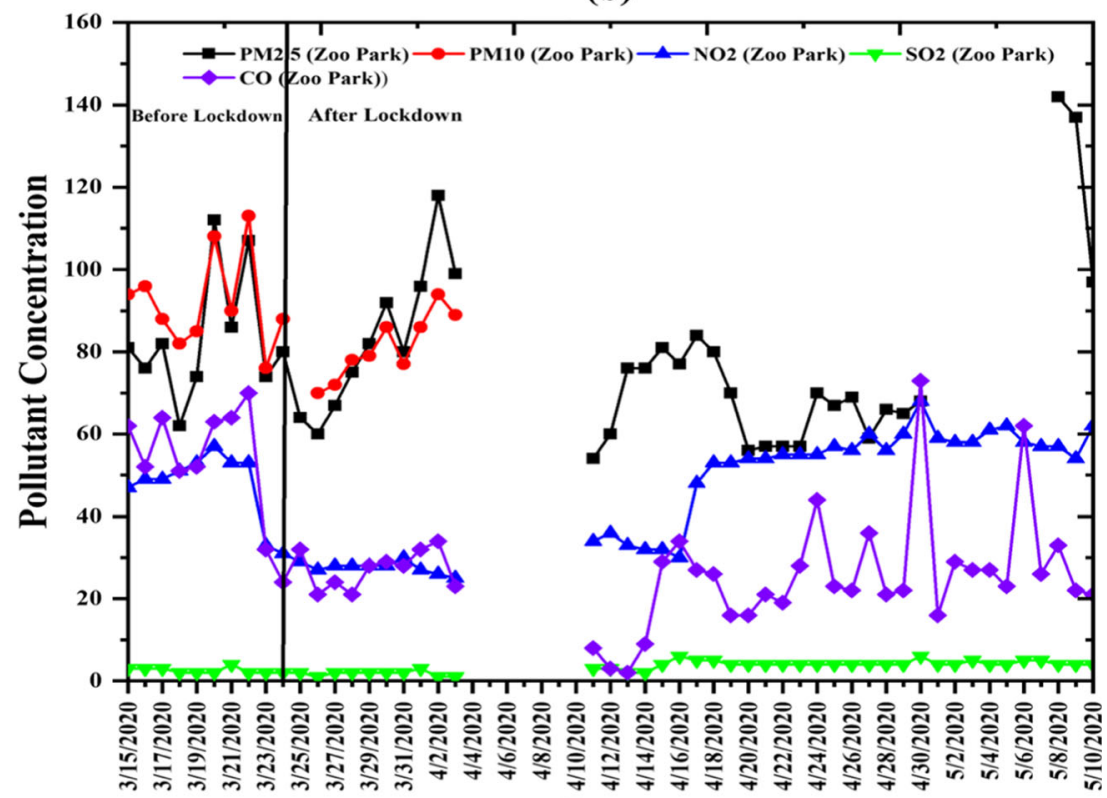

Date investigated the improvements in air quality by using satellitebased measurement and reported a remarkable improvement in Air Quality Index (AQI) from 130 (on 14 January 2020) to 47 on 7 April 2020 over Hyderabad. Similar trends observed at Sanathagar, where the pollution level before the lockdown was found as $52 \pm 14.94 \mu \mathrm{g} / \mathrm{m}^{3}$ of $\mathrm{PM}_{2.5}, 74.85 \pm 10.47 \mu \mathrm{g} /$ $\mathrm{m}^{3}$ of $\mathrm{PM}_{10}, 24.71 \pm 14.06 \mu \mathrm{g} / \mathrm{m}^{3}$ of $\mathrm{NO}_{2}$, a consistent $3 \mu \mathrm{g}$ / $\mathrm{m}^{3}$ of $\mathrm{SO}_{2}$ and $52.28 \pm 10.51 \mu \mathrm{g} / \mathrm{m}^{3}$ (CO). By the end of eight weeks, $\mathrm{PM}_{10}, \mathrm{PM}_{2.5}, \mathrm{NO}_{2}$, and $\mathrm{CO}$ reduced by 18, 23, 73 and $47 \%$, respectively. The level $\mathrm{SO}_{2}$ was almost consistent with $2 \mu \mathrm{g} / \mathrm{m}^{3}$ without any significant variation during the entire lockdown period. The highest and lowest levels of pollutants during lockdown were 107 and $16 \mu \mathrm{g} / \mathrm{m}^{3}$ for $\mathrm{PM}_{2.5}, 85$ and $21 \mu \mathrm{g} / \mathrm{m}^{3}$ for $\mathrm{PM}_{10}, 22$ and $3 \mu \mathrm{g} / \mathrm{m}^{3}$ for $\mathrm{NO}_{2}, 65$ and $13 \mu \mathrm{g} / \mathrm{m}^{3}$ for $\mathrm{CO} . \mathrm{SO}_{2}$ concentration were consistent to $2 \mu \mathrm{g} / \mathrm{m}^{3}$ all over the time (Fig. 3b).

\subsection{Lucknow, Uttar Pradesh, India}

Lucknow is also a major million-plus city with a very high rate of expansion and industrial development. Talkatora industrial area is a significant emission point in the town to show a drastic improvement in air quality after lockdown implementation. The average weekly concentration before the lockdown was $206.42 \pm 83.89,36.71 \pm 13.18,4.28 \pm 2.21$ and $48.71 \pm$ $2.21 \mu \mathrm{g} / \mathrm{m}^{3}$ of $\mathrm{PM}_{2.5}, \mathrm{NO}_{2}, \mathrm{SO}_{2}$, and $\mathrm{CO}$ respectively. The concentration of $\mathrm{PM}_{2.5}(52 \%), \mathrm{NO}_{2}(63 \%)$, and only $6 \%$ $\left(\mathrm{SO}_{2}\right)$ have decreased by many-folds, as well as $\mathrm{CO}$ also 
increase by $13 \%$ after lockdown. The reason may be either local emissions from households or the long-term emissions of plywood and paint industries in the nearby area (Fig. 4a).

Lockdown impacted the particulate pollutant levels in Lalbagh to a greater extent where the weekly average values of the pollutants reported $208.42 \pm 69.80,22.33 \pm 6.28,5.42$ \pm 0.53 and $54.85 \pm 0.69 \mu \mathrm{g} / \mathrm{m}^{3}$ of $\mathrm{PM}_{2.5}, \mathrm{NO}_{2}, \mathrm{SO}_{2}$, and $\mathrm{CO}$ respectively. A dramatic reduction of $30 \%$ in $\mathrm{PM}_{2.5}$ was found within a week and further to $52 \%$ by the seventh week of lockdown. $\mathrm{NO}_{2}$ and $\mathrm{SO}_{2}$ declined by 17 and $13 \%$ respectively, although there was no significant change observed in $\mathrm{CO}$ concentration (Fig. 4a). After lockdown, the highs and lows levels of pollutant were $237 \mu \mathrm{g} / \mathrm{m}^{3}$ and $40 \mu \mathrm{g} / \mathrm{m}^{3}\left(\mathrm{PM}_{2.5}\right)$, $40 \mu \mathrm{g} / \mathrm{m}^{3}$ and $14 \mu \mathrm{g} / \mathrm{m}^{3}\left(\mathrm{NO}_{2}\right), 7 \mu \mathrm{g} / \mathrm{m}^{3}$ and $3 \mu \mathrm{g} / \mathrm{m}^{3}$ $\left(\mathrm{SO}_{2}\right), 56 \mu \mathrm{g} / \mathrm{m}^{3}$ and $30 \mu \mathrm{g} / \mathrm{m}^{3}(\mathrm{CO})$ respectively.

Regions of Central School also performed well in terms of pollution reduction during the lockdown phase.
The 51 and $71 \%$ reduction of $\mathrm{PM}_{2.5}$ and $\mathrm{NO}_{2}$ concentrations have reported in the seventh week of lockdown. However, a slight decrease of $11 \%$ in $\mathrm{CO}$ and although $25 \%$ increment in $\mathrm{SO}_{2}$ level have reported. The average mass concentration of pollutants after 1 st week of lockdown was $110 \pm 51.42 \mu \mathrm{g} / \mathrm{m}^{3}\left(\mathrm{PM}_{2.5}\right), 42.28 \pm$ $17.53 \mu \mathrm{g} / \mathrm{m}^{3}, 6.14 \pm 1.67 \mu \mathrm{g} / \mathrm{m}^{3}\left(\mathrm{SO}_{2}\right)$ and $51.71 \pm$ $6.15 \mu \mathrm{g} / \mathrm{m}^{3}$ (CO). The trends in air parameters have inscribed in Fig. 4a. A recent study by (Srivastava et al. 2020) in two major polluted cities (Delhi and Lucknow) of India indicated that the AQI fell to good and satisfactory levels in all the monitoring sites and a substantial decline in pollutants as compared to the similar period of the last year. Several studies suggested the improvements in the air quality due to impact of lockdown over India (Kumari and Toshniwal 2020; Gautam 2020).
Fig. 4 Daily variation of atmospheric pollutant over (a) Lucknow (a1; $\mathrm{PM}_{10}, \& \mathrm{PM}_{2.5}$, and a2; $\mathrm{NO}_{2}, \mathrm{SO}_{2} \& \mathrm{CO}$ ) and (b) Chandigarh during 15

March 2020 to 10 April 2020. A dark black line is used to distinguish the before (before 24 March 2020) and after (after 24

March 2020) lockdown period

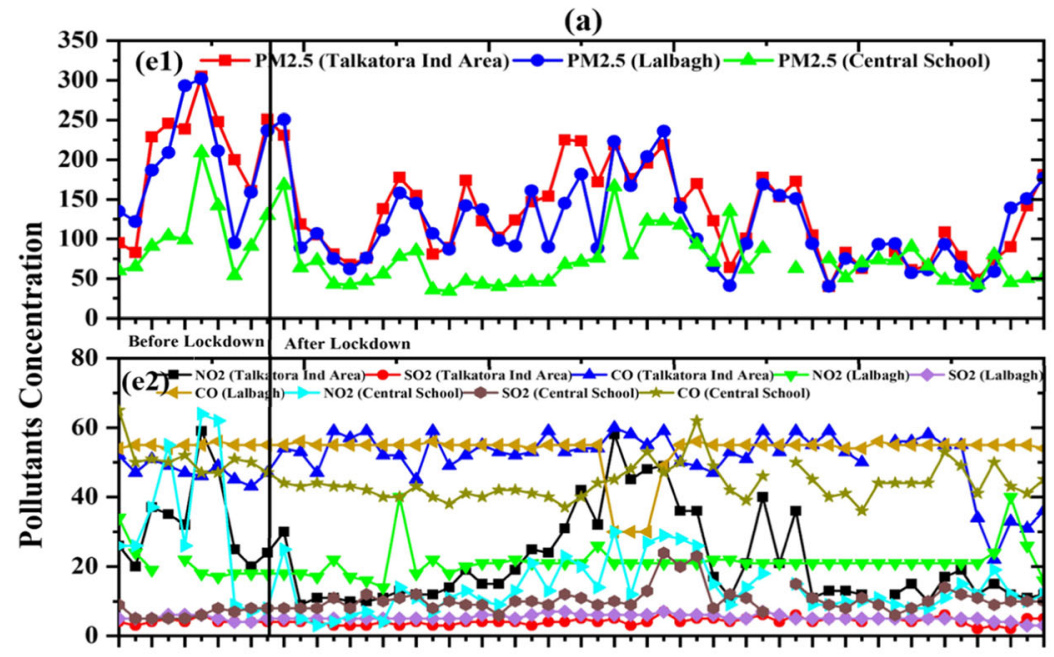

(b)

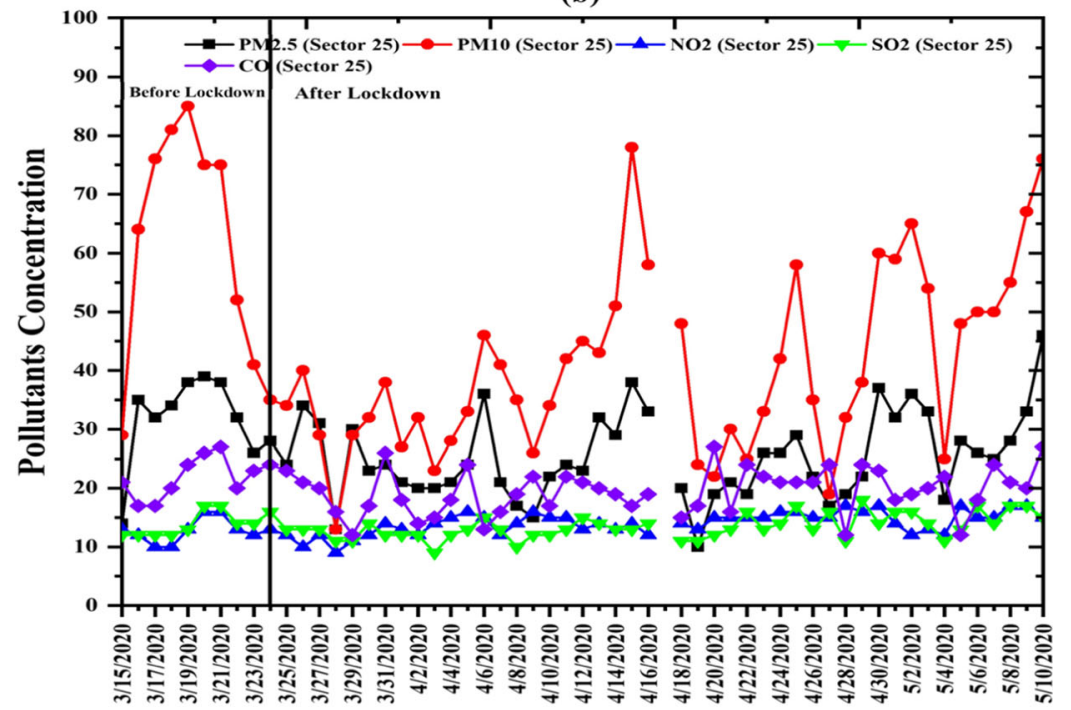

Date 
Fig. 5 Daily variation of pollution parameters (a) Kolkata (a1; $\mathrm{PM}_{10}, \mathrm{PM}_{2.5}$ \& a2: $\mathrm{NO}_{2}$, $\mathrm{SO}_{2} \& \mathrm{CO}$ ) and (b) Ahmedabad during 15 March 2020 to 10 April 2020. A dark black line is used to distinguish the before (before 24 March 2020) and after (after 24

March 2020) lockdown period

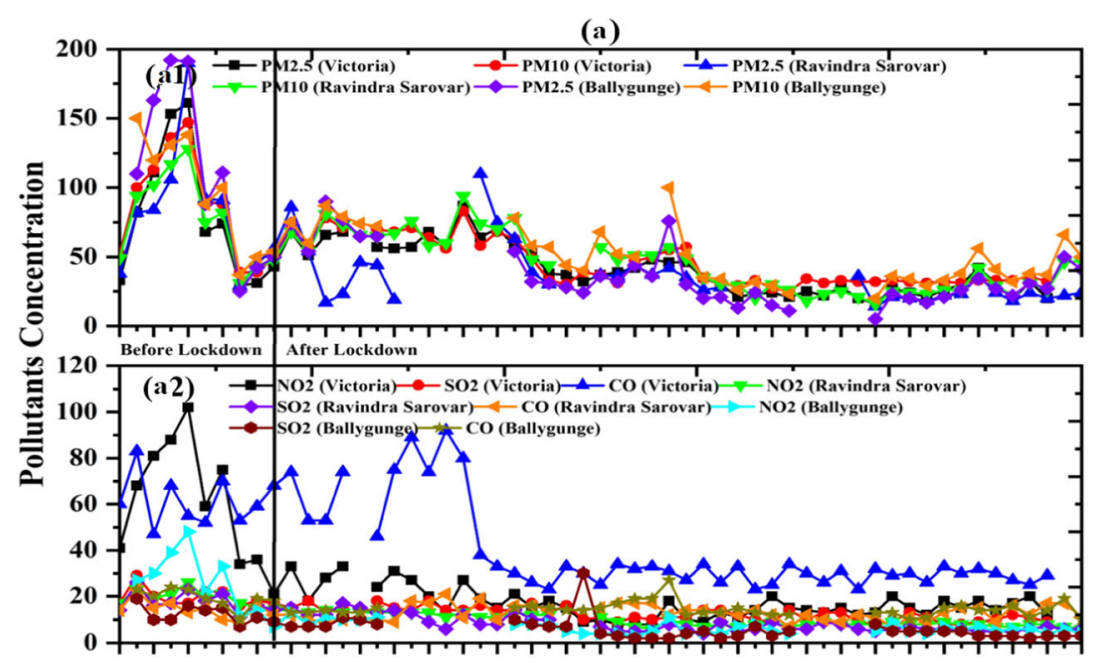

(b)

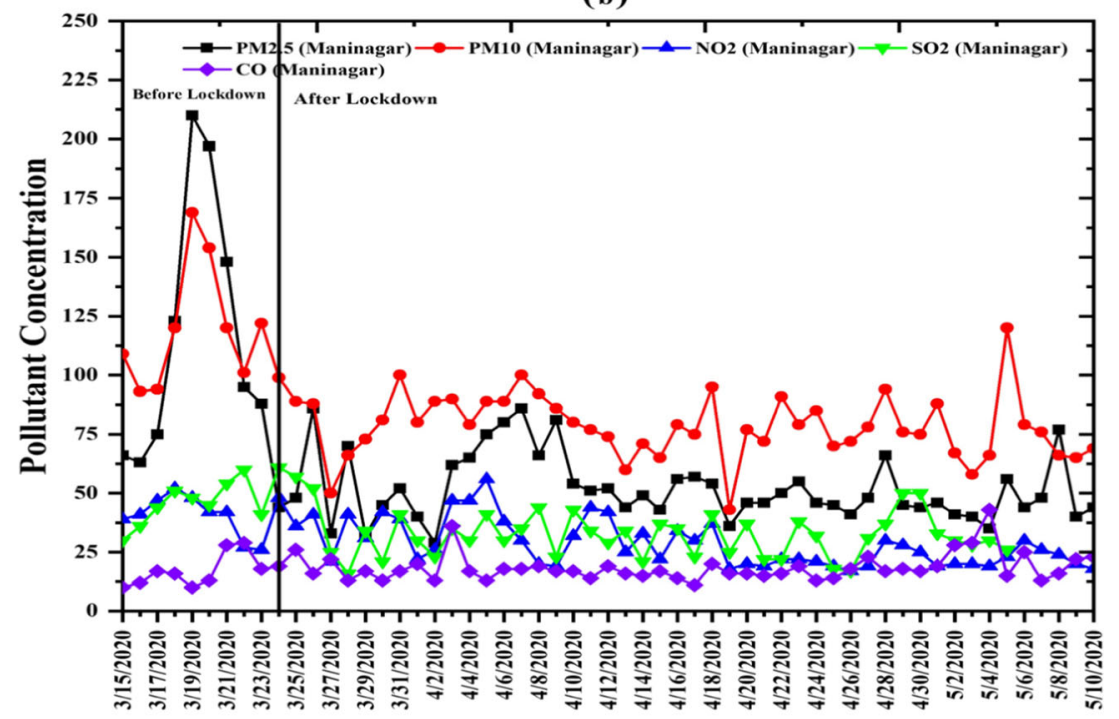

Date

\subsection{Chandigarh, India}

Chandigarh, without any doubt, is one of the cleanest capitals (Haryana \& Punjab) in the country, whether in terms of air pollution and other solid waste pollution. The pollution concentrations were way lower in the capital even before the lockdown and further became cleaner after the lockdown implementation. Before-lockdown pollutant concentration was $32.85 \pm 8.68 \mu \mathrm{g} / \mathrm{m}^{3}$ of $\mathrm{PM}_{2.5}, 69.28 \pm 18.90 \mu \mathrm{g} / \mathrm{m}^{3}$ of $\mathrm{PM}_{10}$, $12.85 \pm 2.47 \mu \mathrm{g} / \mathrm{m}^{3}$ of $\mathrm{NO}_{2}, 13.57 \pm 2.37 \mu \mathrm{g} / \mathrm{m}^{3}$ of $\mathrm{SO}_{2}$ and $21.71 \pm 4.07 \mu \mathrm{g} / \mathrm{m}^{3}$ of $\mathrm{CO}$, and within a week, there was a fall of $26.85 \pm 7.03 \mu \mathrm{g} / \mathrm{m}^{3}$ in $\mathrm{PM}_{2.5}, 34.85 \pm 12.04 \mu \mathrm{g} / \mathrm{m}^{3}$ in $\mathrm{PM}_{10}$ and $11.57 \pm 1.51$ in $\mathrm{NO}_{2}$ (Fig. 4b). The concentration of $\mathrm{SO}_{2}$ and $\mathrm{CO}$ consistently remained the unchanged during the entire duration, with an average of $13.4 \mu \mathrm{g} /$ and $19.63 \mu \mathrm{g} / \mathrm{m}^{3}$, respectively.

\subsection{Kolkata, West Bengal, India}

Kolkata performed the best in all the state capitals in terms of pollution reduction, where all the three selected monitoring stations showed a decrease in pollution levels. The pollution levels at Victoria before a week of lockdown were $97.42 \pm$ $46.75 \mu \mathrm{g} / \mathrm{m}^{3}\left(\mathrm{PM}_{2.5}\right), 103 \pm 31.95 \mu \mathrm{g} / \mathrm{m}^{3}\left(\mathrm{PM}_{10}\right), 73.42 \pm$ $19.90 \mu \mathrm{g} / \mathrm{m}^{3}\left(\mathrm{NO}_{2}\right), 20.57 \pm 4.35 \mu \mathrm{g} / \mathrm{m}^{3}\left(\mathrm{SO}_{2}\right)$ and $62.14 \pm$ $12.37 \mu \mathrm{g} / \mathrm{m}^{3}$ (CO) which declined by $70 \%$ for $\mathrm{PM}_{2.5}, 68 \%$ for $\mathrm{PM}_{10}, 78 \%$ for $\mathrm{NO}_{2}, 52 \%$ for $\mathrm{SO}_{2}$ and $54 \%$ for $\mathrm{CO}$. The maximum and minimum values for pollutants after lockdown were 87 and $16 \mu \mathrm{g} / \mathrm{m}^{3}$ of $\mathrm{PM}_{2.5}, 83$ and $25 \mu \mathrm{g} / \mathrm{m}^{3}$ of $\mathrm{PM}_{10}$, $36 \mu \mathrm{g} /$ and $8 \mu \mathrm{g} / \mathrm{m}^{3}$ of $\mathrm{NO}_{2}, 18 \mu \mathrm{g} /$ and $8 \mu \mathrm{g} / \mathrm{m}^{3}$ of $\mathrm{SO}_{2}$ and $92 \mu \mathrm{g} /$ and $23 \mu \mathrm{g} / \mathrm{m}^{3}$ of CO (Fig. $5 \mathrm{a}$ ).

Rabindra Sarovar was also found clean due to the lockdown implementation. The average concentration just before lockdown were $97.57 \pm 46.75 \mu \mathrm{g} / \mathrm{m}^{3}\left(\mathrm{PM}_{2.5}\right), 92.42 \pm$ $26.65 \mu \mathrm{g} / \mathrm{m}^{3}\left(\mathrm{PM}_{10}\right), 20.85 \pm 2.96 \mu \mathrm{g} / \mathrm{m}^{3}\left(\mathrm{NO}_{2}\right), 19.28 \pm$ 
Fig. 6 Daily variation Air Quality Index for (a) Mumbai, (b) Delhi, (c) Lucknow, (d) Kolkata, and (e) Bangalore, Sanathagar, Hyderabad, Chandigarh \& Ahmedabad before lockdown (before 24 March 2020) and after lockdown (after 24 March 2020 to 10 May 2020)

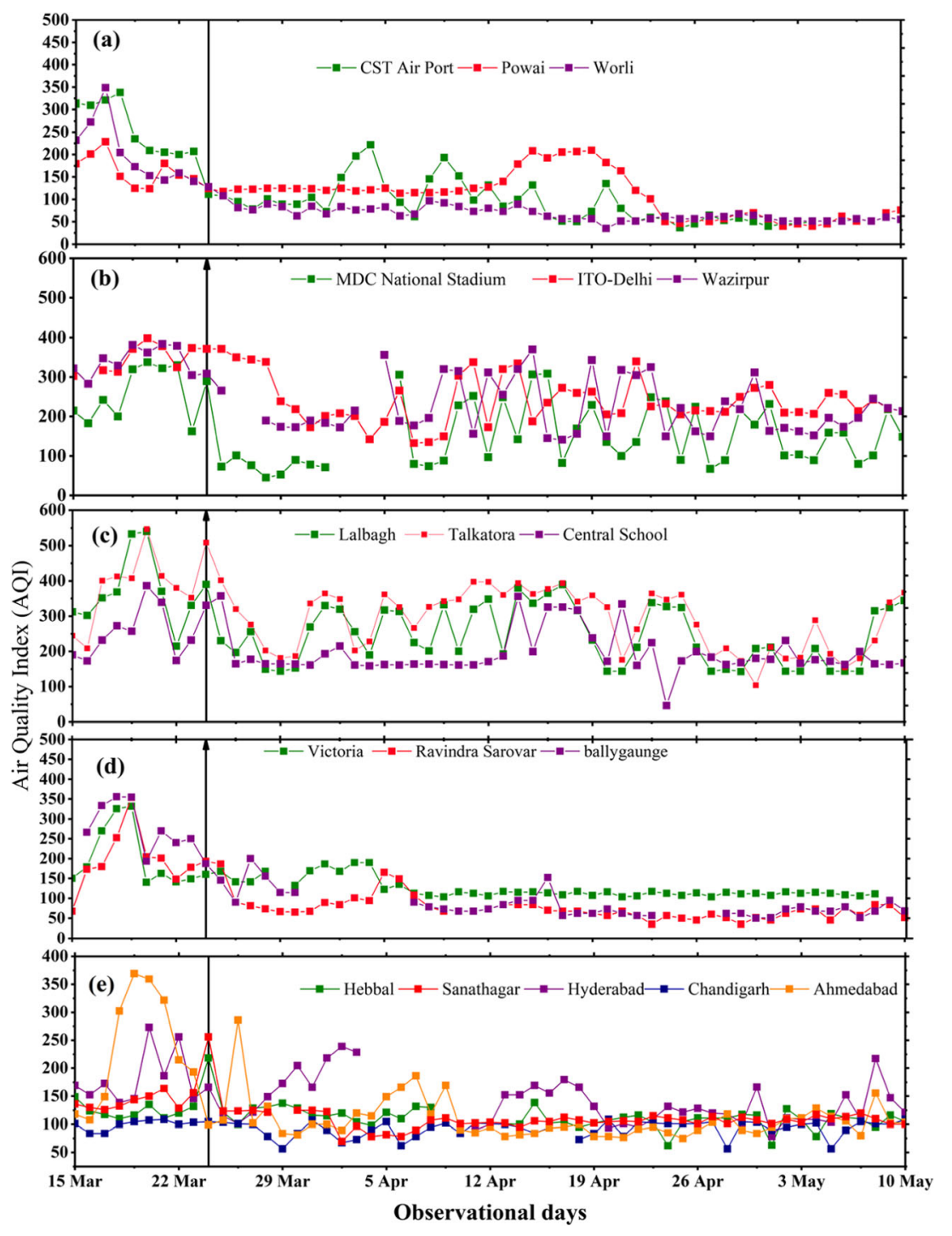

$4.23 \mu \mathrm{g} / \mathrm{m}^{3}\left(\mathrm{SO}_{2}\right)$ and $15.28 \pm 4.02 \mu \mathrm{g} / \mathrm{m}^{3}$ (CO) with the highest level of $190 \mu \mathrm{g} / \mathrm{m}^{3}\left(\mathrm{PM}_{2.5}\right), 128 \mu \mathrm{g} / \mathrm{m}^{3}\left(\mathrm{PM}_{10}\right)$, $26 \mu \mathrm{g} / \mathrm{m}^{3}\left(\mathrm{NO}_{2}\right), 23 \mu \mathrm{g} / \mathrm{m}^{3}\left(\mathrm{SO}_{2}\right)$ and $23 \mu \mathrm{g} / \mathrm{m}^{3}$ (CO). A dramatic change of $75,63,64 \%, 70$ and $8.3 \%$ have reported in the $\mathrm{PM}_{2.5}, \mathrm{PM}_{10}, \mathrm{SO}_{2}, \mathrm{NO}_{2}$, and $\mathrm{CO}$ concentration during the seventh week of lockdown.

The highest and lowest concentration of pollutant during the lockdown phase were 110 and $14 \mu / \mathrm{m}^{3}$ of $\mathrm{PM}_{2.5}, 94 \mu \mathrm{g} /$ $\mathrm{m}^{3}$ and $16 \mu \mathrm{g} / \mathrm{m}^{3}$ of $\mathrm{PM}_{10}, 17 \mu \mathrm{g} /$ and $6 \mu \mathrm{g} / \mathrm{m}^{3}$ of $\mathrm{NO}_{2}, 17 \mu \mathrm{g} /$ and $4 \mu \mathrm{g} / \mathrm{m}^{3}$ of $\mathrm{SO}_{2}$ and $21 \mu \mathrm{g} /$ and $7 \mu \mathrm{g} / \mathrm{m}^{3}$ of $\mathrm{CO}$ (Fig. 5a).

Ballygunge saw a drop of $77 \%$ of $\mathrm{PM}_{2.5}, 63 \%$ drop in $\mathrm{PM}_{10}$, a major decline of $83 \%$ in $\mathrm{NO}_{2}, 77 \%$ in $\mathrm{SO}_{2}$, and drop of $32 \%$ in $\mathrm{CO}$ concentration by the seventh week of lockdown implementation. The weekly average concentration just before lockdown was $142.5 \pm 42.25 \mu \mathrm{g} / \mathrm{m}^{3}\left(\mathrm{PM}_{2.5}\right), 121.16 \pm$ $23.49 \mu \mathrm{g} / \mathrm{m}^{3}\left(\mathrm{PM}_{10}\right), 33.16 \pm 9.23 \mu \mathrm{g} / \mathrm{m}^{3}\left(\mathrm{NO}_{2}\right), 14 \pm$ $3.52 \mu \mathrm{g} / \mathrm{m}^{3}\left(\mathrm{SO}_{2}\right)$ and $21 \pm 2.75 \mu \mathrm{g} / \mathrm{m}^{3}(\mathrm{CO})$ with maximum of $192 \mu \mathrm{g} / \mathrm{m}^{3}\left(\mathrm{PM}_{2.5}\right), 150 \mu \mathrm{g} / \mathrm{m}^{3}\left(\mathrm{PM}_{10}\right), 48 \mu \mathrm{g} / \mathrm{m}^{3}\left(\mathrm{NO}_{2}\right)$,
$19 \mu \mathrm{g} / \mathrm{m}^{3}\left(\mathrm{SO}_{2}\right)$ and $24 \mu \mathrm{g} / \mathrm{m}^{3}$ (CO). The highest and lowest concentration of pollutant during the lockdown phase were 90 and $5 \mu \mathrm{g} / \mathrm{m}^{3}$ of $\mathrm{PM}_{2.5}, 100$ and $20 \mu \mathrm{g} / \mathrm{m}^{3}$ of $\mathrm{PM}_{10}, 14$ and $4 \mu \mathrm{g} / \mathrm{m}^{3}$ of $\mathrm{NO}_{2} 30$ and $2 \mu \mathrm{g} / \mathrm{m}^{3}$ of $\mathrm{SO}_{2}$, and 27 and $10 \mu \mathrm{g} / \mathrm{m}^{3}$ of $\mathrm{CO}$ (Fig. 5a).

\subsection{Ahmedabad, Gujarat, India}

Ahmedabad is comparatively a clean city in terms of pollution levels, where the regular days observe pollution levels below the required standards. The lockdown further helped to clean the air to a greater extent. The weekly average pollutant concentration before the lockdown was $126 \pm 61.59 \mu \mathrm{g} / \mathrm{m}^{3}$ of $\mathrm{PM}_{2.5}, 122.7 \pm 28.95 \mu \mathrm{g} / \mathrm{m}^{3}$ for $\mathrm{PM}_{10}, 44.42 \pm 4.64 \mu \mathrm{g} / \mathrm{m}^{3}$ for $\mathrm{NO}_{2}, 44 \pm 8.42 \mu \mathrm{g} / \mathrm{m}^{3}$ for $\mathrm{SO}_{2}$ and $15.14 \pm 6.28 \mu \mathrm{g} / \mathrm{m}^{3}$ of $\mathrm{CO}$ observed (Fig. 5b). However, a drop of 62, 39, 49 and $36 \%$ in $\mathrm{PM}_{2.5}, \mathrm{PM}_{10}, \mathrm{NO}_{2}$, and $\mathrm{SO}_{2}$ have seen during the lockdown period. $\mathrm{CO}$ concentration remained more or less 
Fig. 7 Before-lockdown (10 March 2020 to 24 March 2020) period (a) variation of Air Quality Index during (AQI) during 2019 \& 2020 over monitoring stations and (b) the percentage change in $\mathrm{AQI}$

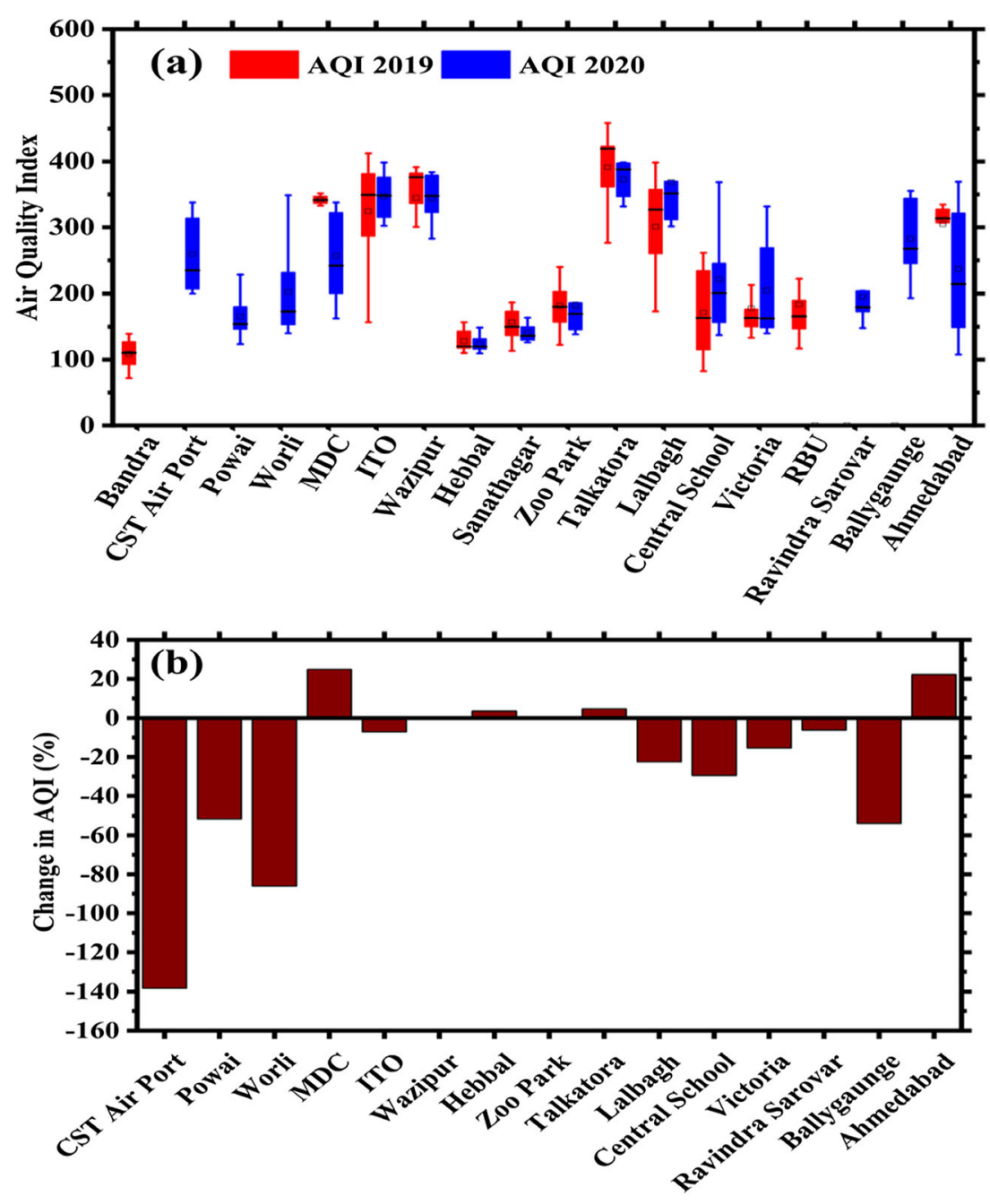

Monitoring stations the same, with an average value of $17 \mu \mathrm{g} / \mathrm{m}^{3}$ during the lockdown. In Gujrat, India, the $\mathrm{PM}_{10}, \mathrm{PM}_{2.5}$, and $\mathrm{NO}_{2}$ have declined to $32-80 \%, 38-78 \%$, and $30-84 \%$, respectively, with an overall 58\% improvement in AQI (Selvam et al. 2020).

In terms of pollution decline, not only in India, similar trends were seen across the world, where most of the populous states had seen a decrease in pollution levels. (Bao and Zhang 2020) studied the impact and found a decline of 6.76, 5.93, 13.60, 24.67 and $4.58 \%$ in $\mathrm{SO}_{2}, \mathrm{PM}_{2.5}, \mathrm{PM}_{10}, \mathrm{NO}_{2}$, and $\mathrm{CO}$ respectively after lockdown over 44 cities in north china. Lal et al. (2020) also stated that there had been a substantial decrease in gaseous emissions due to the forced shut down of many countries in this pandemic phase. Dantas et al. (2020) studied the impact of lockdown in Rio de Janeiro and found a decline of $\mathrm{CO}$ and $\mathrm{NO}_{2}$ concentrations, although there was no significant change in $\mathrm{PM}_{10}$ level.

\subsection{Air Quality Index (AQI) over eight polluted cities in India}

AQI is a crucial tool to understand the overall health of air of any location. The AQI was calculated before lockdown and after a lockdown in India (Fig. 6). All the sites showed a significant reduction in the air quality levels after 24 March 2020. In the Mumbai, Two sites (Worli and CST airport) show a dramatic change (66 and 67\%) in the AQI. Only a $33 \%$ reduction of AQI has observed at Powai (Fig. 6a). The AQI has improved from reduced range (251-350) to moderated range (101 to 250) during lockdown (Table 2). In Delhi, a significant declination in AQI has found in the range of $29 \%$ to $41 \%$ (Fig. 6b). The AQI of Lucknow (Fig. 6c) and Kolkata (Fig. 6d) have observed in the range of $25 \%-70 \%$ (Ballygaunge). After 5 April 2020, all the stations showed significantly low variation in the moderate polluted or within the satisfactory range (51-100). Chandigarh, Ahmedabad, Bangalore, and Hyderabad have only one station in which Chandigarh has satisfactory AQI (51-100) in both conditions, 
Fig. 8 After lockdown (25 March 2020 to 10 May 2020) period (a) variation of Air Quality Index during (AQI) during 2019 \& 2020 over monitoring stations and (b) the percentage change in AQI year 2019

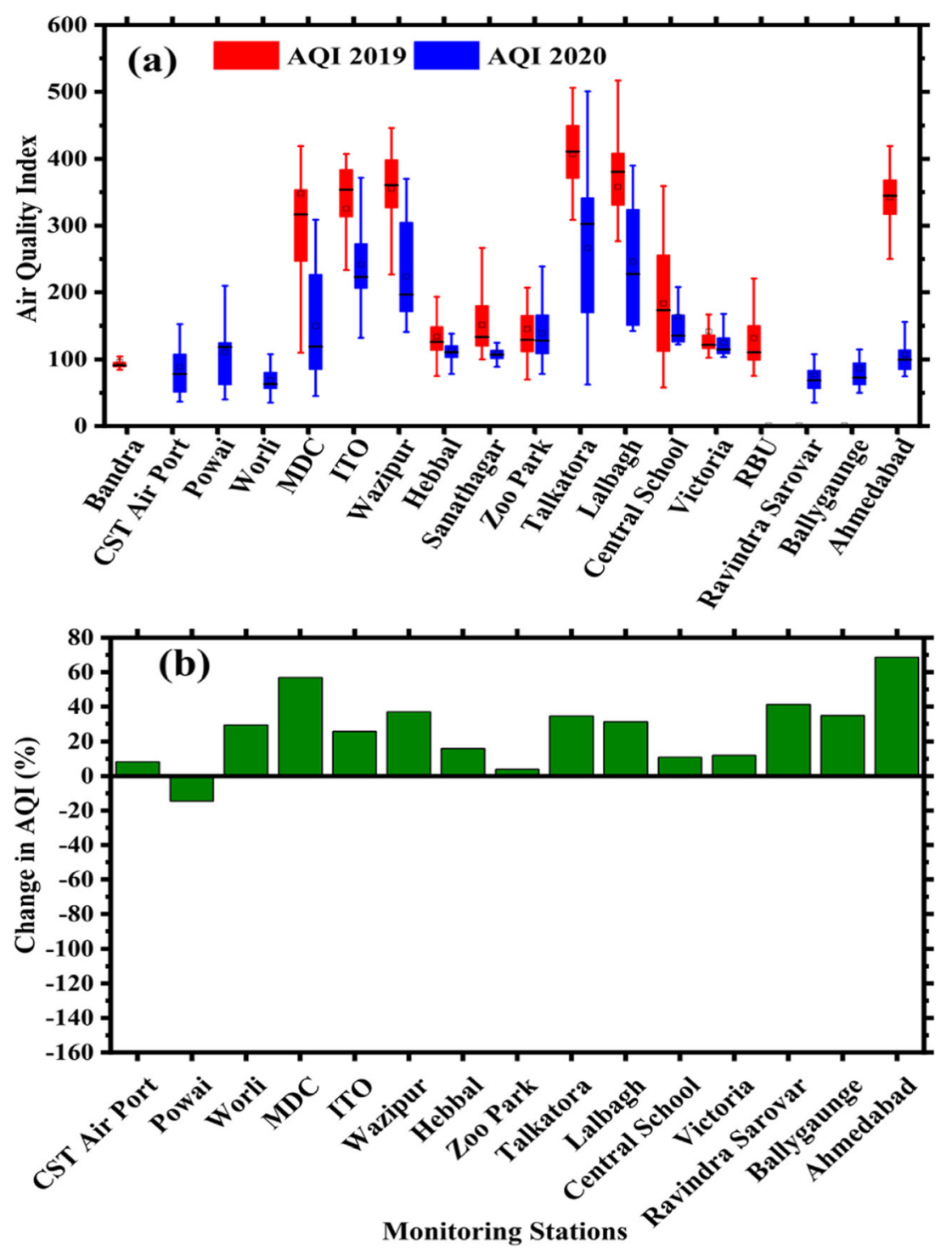

with a minimum reduction of $7 \%$ and Bangalore experienced $11 \%$ reduction with moderately polluted (Fig. 6e). Ahmedabad and Hyderabad showed a significant decrease of 55 and $23 \%$ with the moderately polluted status (101 to 250), respectively. Srivastava et al. (2020) described the impact of lockdown over Delhi and Lucknow, whereas Singh and Chauhan (2020) analyzed the for the Kolkata, Mumbai, Hyderabad, and Delhi.

\subsection{AQI comparison with the year 2019}

A comparative study is also included in this manuscript for the same period (15 March to 10 May) for both years 2019 and 2020. During our observation, the data set for Chandigarh, Mumbai, and Kolkata were unavailable on the CPCB website for the selected period (15 March 2019 to 10 May 2019). So, to resolve the issue, we look forward to the nearest available stations and consider Bandra for Mumbai and Rabindra Bharti
University (RBU) for Kolkata during comparison (Fig. 7 and Fig. 8). Before lockdown period, the AQI was relatively high as compared to 2020 at CST airport, Powai, Worli, MDC, Sanathagar, Zoopark, Talkatora, Ravindra Sarovar, Ballygaunge, and Ahmedabad (Fig. 7a). In contrast, some other monitoring stations such as Bandra, I.T.O., Wazipur, Lalbagh, Central School, Victoria, and RBU have low variation in AQI as compare to the year 2020 (Fig. 7a). The CST airport, Powai, Worli, Ballygaunge show a higher percentage change in the AQI as compare to the remaining stations from $-53.80 \%$ to $-138.41 \%$. However, Lalbagh, Central School, Victoria, ITO, And Ravindra Sarovar show relatively low percentage change in the range of $-7 \%$ to $-29.3 \%$, as well as

Fig. 9 Air Back Mass trajectory over (a) Mumbai, (b) Delhi, (c) Bangalore, (d) Hyderabad, (e) Lucknow, (f) Chandigarh, (g) Kolkata and (h) Ahmedabad at $500 \mathrm{~m}$ during 15 March 2020 to 10 May 2020 

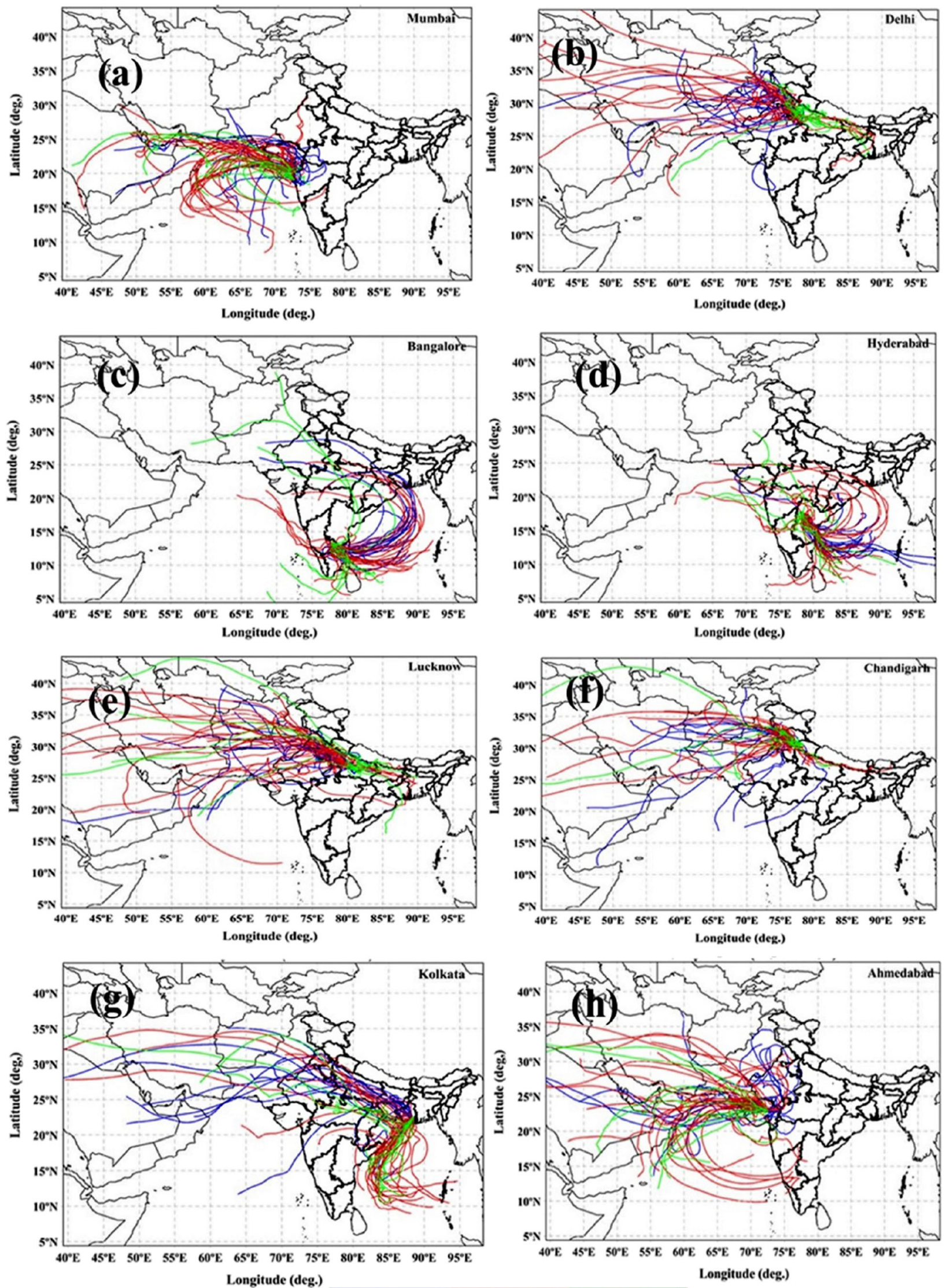

March 2020 April 2020 May 2020

Korean Meteorological Society Springer 
MDC, Ahmedabad, and Talkatora indicates the difference in the AQI from $0.26 \%$ to $24.87 \%$ (Fig. 7 b). But the implication of lockdown over India has changed the whole picture of APs.

After the implication of lockdown, the variation in AQI over selected station is given in the Fig. 8a. A significant change in the AQI sported over the Ahmedabad, Worli, I.T.O., Talkatora, Lalbagh, and Ballygaunge in the range of 25.76 to $68.55 \%$. In contrast, Zoo Park, C.S.T., Central School, and Victoria show relatively low variation from 3 to $14.50 \%$ (Fig. $8 b)$. At Powai, AQI has been improved up to $37.17 \%$ after lockdown, but also shows a negative change of $-14.38 \%$ as compared to year 2019 (Fig. 8b) probably due to positive change in the traffic volume in the year 2020 as compare to 2019. Sharma et al. (2020) observed a $30 \%$ decline in AQI in 2020 as compared to 2019, 2018, 2017.

\subsection{Air back mass trajectory (ABMT) analysis}

To understand the impact of transportation of air contaminants and their geographical origin, a five days ABMT was plotted at an altitude of $500 \mathrm{~m}$ (above ground level) during March 2020 to May 2020. The AMBT at $500 \mathrm{~m}$ were also calculated by the many researcher such as Hernández-Ceballos et al. 2011; Rengarajan et al. 2007; Yang et al. 2017. Now the ABMT for Mumbai, Delhi, Bangalore, Hyderabad, Lucknow, Ahmedabad, Chandigarh, and Kolkata have selected for the study. In the Mumbai (Fig. 9a), Delhi (Fig. 9b), Lucknow (Fig. 9c), Chandigarh (Fig. 9f) and Ahmedabad (Fig. 9h), the air mass is coming from Iran, Afghanistan, Pakistan, Saudi Arabia, to the respective location from March 2020 to April 2020. But in the Kolkata (Fig. 9g) and Lucknow (Fig. 9e), the air mass contributing from both branches, i.e., Gulf Countries, the Bay of Bengal, and Arabian Sea the during observation with the pollutants from Indian Gangetic Plain. But some other locations in the southern part of India such as Bangalore (Fig. 9c) and Hyderabad (Fig. 9d) were influenced by the long-range transportation from Iran, Afghanistan via Pakistan as well from Rajasthan, Madhya Pradesh, Odisha, and the Bay of Bengal to both locations. The APs fluctuations usually governed by the long-range and local transportation of pollutants. ABMT has well described by Sandeep et al. (2013); Sinha et al. (2013); Yerramsetti et al. (2013); Pawar et al. (2015); Mallik et al. (2014) and Deshpande et al. (2015) over Mumbai, Delhi, Hyderabad, Lucknow, Chandigarh, Kolkata, and Ahmedabad respectively. They also influenced by the long-range transport of pollutants from Gulf countries, European and African countries.

\section{Conclusion}

The COVID-19 has forced to apply full or partial lockdown around the world. It reflects a dramatic change in the levels of APs all around due to the prohibition of outdoor activities, such as transportation, industrial activities (accepts essential sectors such as power, pharma, and food industries), tourism, construction, and other anthropogenic activities. The declining trends of the air contaminants appeared over the entire India. The lockdown phase has opened a new dimension to look into the aspects of abating air pollution in the most polluted and populated location. Kolkata, Mumbai, and Lucknow were among the cities that showed a significant improvement in the levels of APs, mainly due to low anthropogenic pressure (activities). Delhi, the capital city of India, could not provide enthusiastic results. Still, abatement policies can be developed by the state government, including measures like weekend lockdowns, control over heavy vehicle emissions, and movement of private vehicles in a polluted location and promoting green technologies in vehicles. Cities, including Chandigarh, Bangalore, and Ahmedabad, were already in a clean condition, even before the lockdown, and showed further improvements. Such places can act as a buffer to control the air pollution by the trans-boundary movement of air mass and also can further study for the ways of their pollution control policies. The mass back trajectory analysis suggests the contribution of the long-range transition of pollutants from Iran, Afghanistan, Saudi Arabia, as well as a regional contribution from Indian Gagatic plains and Delhi Non-capital region in the form of the several peaks after lockdown. The AQI has dramatically reduced from 7 to $67 \%$ over Chandigarh and Ballygaunge (Kolkata), after the adoption of lockdown in India. Air Quality has remarkably improved from poor to moderately polluted and further satisfactory status (Table 2). The AQI has also improved up to $68.55 \%$ as compared to 2019 after lockdown period.

Acknowledgments ASG thanks to Prof. Annpurna Nautiyal, ViceChancellor, HNBGU. Srinagar, Garhwal Uttarakhand \& Head, Department of Physics, HNBGU. Srinagar for encouragement and providing the necessary infrastructure facility for this study. ASG is also thankful to Department of Science and Technology, Government of India for funding support under, Climate Change Programme (CCP), SPLICE Division, Department of Science \& Technology, Technology Bhavan, New Mehrauli Road, New Delhi-110 016 (DST/CCP/Aerosol/ 83/2017(G) and also Central Pollution Control Board (CPCB) for data of pollution parameters. KB acknowledges DST-Science and Engineering Research Board (SERB), New Delhi, India, for financial support (EEQ/ 2017/000476). AA is thankful to the Dr. R. S. Rawal, Director, G. B. Pant National Institute of Himalayan Environment, Uttarakhand to provide the necessary facilities and infrastructure.

Author contribution Alok Sagar Gautam: Conceptualization, Methodology, Visualization, Writing-Original draft preparation. Sanjeev Kumar: Methodology, Writing-Reviewing and Editing. Sneha Gautam: Conceptualization, Writing-Reviewing and Editing. 
Aryan Anand: Data collection and analysis, Methodology.

Ranjit Kumar: Conceptualization, Methodology, Writing-Reviewing and Editing.

Abhishek Joshi: Data collection and analysis, Methodology.

Kuldeep Bauddh: Writing-Reviewing and Editing.

Karan Singh: Data collection and analysis, Methodology.

\section{Declarations}

Declaration of competing interest All authors declare that they have no known competing financial interests or personal relationships that can affect the reported work in the presented manuscript.

\section{References}

Akolkar, A.M.S.B.: National air quality index. Cent. Pollut. Control Board. 1-44 (2016)

Azuma, K., Kagi, N., Kim, H., Hayashi, M.: Impact of climate and ambient air pollution on the epidemic growth during COVID-19 outbreak in Japan. Environ. Res. 190, 110042 (2020). https://doi.org/ 10.1016/j.envres.2020.110042

Bao, R., Zhang, A.: Does lockdown reduce air pollution ? Evidence from 44 cities in northern China. Sci. Total Environ. 731, 139052 (2020). https://doi.org/10.1016/j.scitotenv.2020.139052

Berman, J.D., Ebisu, K.: Changes in U.S. air pollution during the COVID-19 pandemic. Sci. Total Environ. 739, 139864 (2020). https://doi.org/10.1016/j.scitotenv.2020.139864

Chauhan, A., Singh, R.P.: Decline in PM 2.5 concentrations over major cities around the world associated with COVID-19. Environ. Res. 187, 109634 (2020). https://doi.org/10.1016/j.envres.2020.109634

Cole, M.A., Elliott, R.J.R., Shimamoto, K.: Industrial characteristics, environmental regulations and air pollution: an analysis of the UK manufacturing sector. J. Environ. Econ. Manage. 50, 121-143 (2005). https://doi.org/10.1016/j.jeem.2004.08.001

Dantas, G., Siciliano, B., Boscaro, B., Cleyton, M., Arbilla, G.: The impact of COVID-19 partial lockdown on the air quality of the city of Rio de Janeiro. Brazil. Sci. Total Environ. 729, 139085 (2020). https://doi.org/10.1016/j.scitotenv.2020.139085

Deshpande, R.D., Dave, M., Padhya, V., Kumar, H., Gupta, S.K.: Water vapour source identification for daily rain events at Ahmedabad in semi-arid western India: wind trajectory analyses. Meteorol. Appl. 22, 754-762 (2015). https://doi.org/10.1002/met.1515

Dixit, S., Tiwari, S.: Archive of SID impact assessment of heavy metal pollution of Shahpura archive of SID. Int. J. Environ. Res. 2, 37-42 (2008)

Draxler, R.R., Hess, G.D.: An overview of the HYSPLIT 4 modelling system for trajectories, dispersion and deposition. Aust. Meteorol. Mag. 47, 295-308 (1998)

Driggin, E., Madhavan, M.V., Bikdeli, B., Chuich, T., Laracy, J., BiondiZoccai, G., Brown, T.S., Der Nigoghossian, C., Zidar, D.A., Haythe, J., Brodie, D., Beckman, J.A., Kirtane, A.J., Stone, G.W., Krumholz, H.M., Parikh, S.A.: Cardiovascular considerations for patients, health care workers, and health systems during the COVID-19 pandemic. J. Am. Coll. Cardiol. 75, 2352-2371 (2020). https://doi.org/10.1016/j.jacc.2020.03.031

Gautam, A.K., Dilwaliya, N., Srivastava, A., Kumar, S., Baudh, K., Singh, D., Gautam, S.: Temporary reduction in air pollution due to anthropogenic activity switch-of during COVID-19 lockdown in northern parts of India. Environmental Development and Sustainability. (2020). https://doi.org/10.1007/s10668-020-00994-6

Gautam, S.: The influence of COVID-19 on air quality in India: a boon or inutile. Bull. Environ. Contam. Toxicol. 104, 724-726 (2020). https://doi.org/10.1007/s00128-020-02877-y
Gautam, S., Hens, L.: SARS-CoV-2 pandemic in India: what might we expect? Environ. Dev. Sustain. 22, 3867-3869 (2020a). https://doi. org/10.1007/s10668-020-00739-5

Gautam, S., Hens, L.: COVID-19: impact by and on the environment, health and economy. Environmental Development and Sustainability. 22, 4953-4954 (2020b). https://doi.org/10.1007/ s10668-020-00818-7

Gautam, S., Hens, L.: SARS-CoV-2 pandemic in India: what might we expect? Environmental Development and Sustainability. 22, 38673869 (2020c)

Gautam, S., Trivedi, U.K.: Global implication of bioaerosol in pandemic. Environmental Development and Sustainability. 22, 3861-3865 (2020)

Ghorani-Azam, A., Riahi-Zanjani, B., Balali-Mood, M., 2016. Effects of air pollution on human health and practical measures for prevention in Iran. J. Res. Med. Sci. 21. https://doi.org/10.4103/1735-1995. 189646

He, G., Pan, Y., Tanaka, T.: The short-term impacts of COVID-19 lockdown on urban air pollution in China. Nat. Sustain. 3, 1005-1011 (2020). https://doi.org/10.1038/s41893-020-0581-y

Hernández-Ceballos, M.A., García-Mozo, H., Adame, J.A., DomínguezVilches, E., Bolívar, J.P., De La Morena, B.A., Pérez-Badía, R., Galán, C.: Determination of potential sources of Quercus airborne pollen in Córdoba city (southern Spain) using back-trajectory analysis. Aerobiologia (Bologna). 27, 261-276 (2011). https://doi.org/ 10.1007/s10453-011-9195-1

IQAir, 2019. World Air Quality Report. 2019 World Air Qual. Rep. 1-22

Kumari, P., Toshniwal, D.: Impact of lockdown measures during COVID-19 on air quality- a case study of India. Int. J. Environ. Health Res. 00, 1-8 (2020). https://doi.org/10.1080/09603123. 2020.1778646

Lal, P., Kumar, A., Kumar, S., Kumari, S., Saikia, P., Dayanandan, A.: Science of the Total environment the dark cloud with a silver lining: assessing the impact of the SARS COVID-19 pandemic on the global environment. Sci. Total Environ. 732, 139297 (2020). https://doi.org/10.1016/j.scitotenv.2020.139297

Mallik, C., Ghosh, D., Ghosh, D., Sarkar, U., Lal, S., Venkataramani, S.: Variability of $\mathrm{SO}, \mathrm{CO}$, and light hydrocarbons over a megacity in eastern India: effects of emissions and transport. Environ. Sci. Pollut. Res. 21, 8692-8706 (2014). https://doi.org/10.1007/ s11356-014-2795-x

Mannucci, P.M., Franchini, M.: Health effects of ambient air pollution in developing countries. Int. J. Environ. Res. Public Health. 14, 1-8 (2017). https://doi.org/10.3390/ijerph14091048

Pawar, H., Garg, S., Kumar, V., Sachan, H., Arya, R., Sarkar, C., Chandra, B.P., Sinha, B.: Quantifying the contribution of longrange transport to particulate matter (PM) mass loadings at a suburban site in the north-western indo-Gangetic plain (NW-IGP). Atmos. Chem. Phys. 15, 9501-9520 (2015). https://doi.org/10. 5194/acp-15-9501-2015

Ramasamy, K., Jayakumar, S., Somasundaram, M.: Enchanted improvements in air quality across India- a Studyfrom COVID-19 lockdown perspective. Adalya J. 9, 101-125 (2020)

Rengarajan, R., Sarin, M.M., Sudheer, A.K.: Carbonaceous and inorganic species in atmospheric aerosols during wintertime over urban and high-altitude sites in North India. J. Geophys. Res. Atmos. 112, 1 16 (2007). https://doi.org/10.1029/2006JD008150

Sandeep, P., Saradhi, I.V., Pandit, G.G.: Seasonal variation of black carbon in fine particulate matter (PM 2.5) at the tropical coastal city of Mumbai, India. Bull. Environ. Contam. Toxicol. 91, 605-610 (2013). https://doi.org/10.1007/s00128-013-1108-2

Selvam, S., Muthukumar, P., Venkatramanan, S., Roy, P.D., Manikanda Bharath, K., Jesuraja, K.: SARS-CoV-2 pandemic lockdown: effects on air quality in the industrialized Gujarat state of India. Sci. Total Environ. 737, 140391 (2020). https://doi.org/10.1016/j. scitotenv.2020.140391 
Sharma, M., Pandey, R., Maheshwari, M., Sengupta, B., Shukla, B.P., Gupta, N.K., Johri, S.: Interpretation of air quality data using an air quality index for the city of Kanpur, India. J. Environ. Eng. Sci. 2, 453-462 (2003). https://doi.org/10.1139/s03-047

Sharma, S., Zhang, M., Anshika, Gao, J., Zhang, H., Kota, S.H.: Effect of restricted emissions during COVID-19 on air quality in India. Sci. Total Environ. 728, 138878 (2020). https://doi.org/10.1016/j. scitotenv.2020.138878

Singh, R.P., Chauhan, A., 2020. Impact of lockdown on air quality in India during COVID-19 pandemic. Air Qual. Atmos. Heal. 13, $921-$ 928. doi.orhttps://doi.org/10.1007/s11869-020-00863-1

Sinha, P.R., Dumka, U.C., Manchanda, R.K., Kaskaoutis, D.G., Sreenivasan, S., Krishna Moorthy, K., Suresh Babu, S.: Contrasting aerosol characteristics and radiative forcing over Hyderabad, India due to seasonal mesoscale and synoptic-scale processes. Q. J. R. Meteorol. Soc. 139, 434-450 (2013). https:// doi.org/10.1002/qj.1963

Srivastava, S., Kumar, A., Bauddh, K., Gautam Sagar, A., Sanjeev, K.: 21 - day lockdown in India dramatically reduced air pollution indices in Lucknow and New Delhi, India. Bull. Environ. Contam. Toxicol. 105, 9-17 (2020). https://doi.org/10.1007/s00128-020-02895-w

The Hindu, 2020 https://www.thehindu.com/static/content/covid/ covidcubemicrosite.html Accessed on 27 December 2020

Yang, W., Wang, G., Bi, C.: Analysis of long-range transport effects on PM2.5 during a short severe haze in Beijing, China. Aerosol Air Qual. Res. 17, 1510-1522 (2017). https://doi.org/10.4209/aaqr. 2016.06.0220

Publisher's Note Springer Nature remains neutral with regard to jurisdictional claims in published maps and institutional affiliations. 